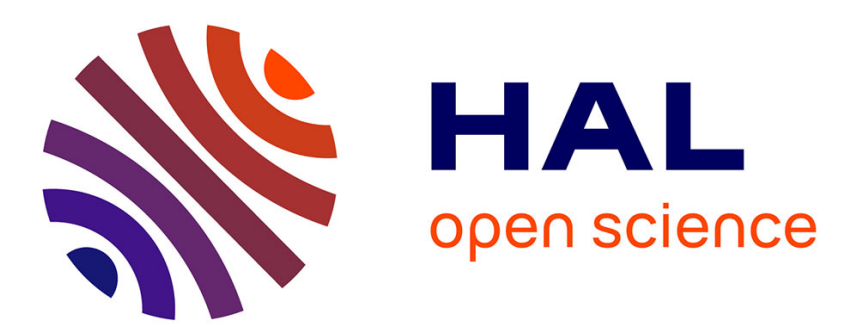

\title{
Removal of PCBs in contaminated soils by means of chemical reduction and advanced oxidation processes
}

\author{
Victoria Rybnikova, Muhammad Usman, Khalil Hanna
}

\section{To cite this version:}

Victoria Rybnikova, Muhammad Usman, Khalil Hanna. Removal of PCBs in contaminated soils by means of chemical reduction and advanced oxidation processes. Environmental Science and Pollution Research, 2016, 23 (17), pp.17035 - 17048. 10.1007/s11356-016-6881-0 . hal-01376264

HAL Id: hal-01376264

https://hal-univ-rennes1.archives-ouvertes.fr/hal-01376264

Submitted on 10 Oct 2016

HAL is a multi-disciplinary open access archive for the deposit and dissemination of scientific research documents, whether they are published or not. The documents may come from teaching and research institutions in France or abroad, or from public or private research centers.
L'archive ouverte pluridisciplinaire HAL, est destinée au dépôt et à la diffusion de documents scientifiques de niveau recherche, publiés ou non, émanant des établissements d'enseignement et de recherche français ou étrangers, des laboratoires publics ou privés. 
Removal of PCBs in contaminated soils by means of chemical reduction and advanced oxidation processes

\author{
V. Rybnikova ${ }^{1}$, M. Usman ${ }^{1,2}$, K. Hanna ${ }^{1}$ *
}

${ }^{1}$ Ecole Nationale Supérieure de Chimie de Rennes, UMR CNRS 6226, 11 Allée de Beaulieu, 35708 Rennes Cedex 7, France.

${ }^{2}$ Institute of Soil and Environmental Sciences, University of Agriculture, Faisalabad 38040, Pakistan

* Corresponding author:

Ecole Nationale Supérieure de Chimie de Rennes

11 Allée de Beaulieu, 35708 Rennes Cedex 7, France.

Tel: 0033223238027

khalil.hanna@ensc-rennes.fr 


\section{Abstract}

Although the chemical reduction and advanced oxidation processes have been widely used individually, very few studies have assessed the combined reduction/oxidation approach for soil remediation. In the present study, experiments were performed in spiked sand and historically contaminated soil by using four synthetic nanoparticles $\left(\mathrm{Fe}^{0}, \mathrm{Fe} / \mathrm{Ni}, \mathrm{Fe}_{3} \mathrm{O}_{4}, \mathrm{Fe}_{3-\mathrm{x}} \mathrm{Ni}_{\mathrm{x}} \mathrm{O}_{4}\right)$. These nanoparticles were tested firstly for reductive transformation of polychlorinated biphenyls (PCBs), and then employed as catalysts to promote chemical oxidation reactions $\left(\mathrm{H}_{2} \mathrm{O}_{2}\right.$ or persulfate). Obtained results indicated that bimetallic nanoparticles $\mathrm{Fe} / \mathrm{Ni}$ showed the highest efficiency in reduction of PCB28 and PCB118 in spiked sand (97\% and 79\% respectively), whereas magnetite $\left(\mathrm{Fe}_{3} \mathrm{O}_{4}\right)$ exhibited a high catalytic stability during the combined reduction/oxidation approach. In chemical oxidation, persulfate showed higher PCB degradation extent than hydrogen peroxide. As expected, the degradation efficiency was found to be limited in historically contaminated soil, where only $\mathrm{Fe}^{0}$ and $\mathrm{Fe} / \mathrm{Ni}$ particles exhibited reductive capability towards PCBs (13 and 18\%). In oxidation step, the highest degradation extents were obtained in presence of $\mathrm{Fe}^{0}$ and $\mathrm{Fe} / \mathrm{Ni}$ (1819\%). The increase in particle and oxidant doses improved the efficiency of treatment, but overall degradation extents did not exceed 30\%, suggesting that only a small part of PCBs in soil was available for reaction with catalyst and/or oxidant. The use of organic solvent or cyclodextrin to improve the PCB availability in soil did not enhance degradation efficiency, underscoring the strong impact of soil matrix. Moreover, a better PCB degradation was observed in sand spiked with extractable organic matter separated from contaminated soil. In contrast to fractions with higher particle size $(250-500 \mu \mathrm{m}$ and $<500 \mu \mathrm{m})$, no PCB degradation was observed in the finest fraction $(\leq 250 \mu \mathrm{m})$ having higher organic matter content. These findings may have important practical implications to promote successively reduction and oxidation reactions in soils and understand the impact of soil properties on remediation performance.

Keywords: PCBs; soil; iron nanoparticles; reductive transformation; oxidation. 


\section{Introduction}

Polychlorinated biphenyls (PCBs) are persistent organic pollutants (POPs) of chemical formula $\mathrm{C}_{12} \mathrm{H}_{10-\mathrm{x}} \mathrm{Cl}_{\mathrm{x}}$, which are known for their toxic, mutagenic and carcinogenic effects (ATSDR 2000; Porta and Zumeta 2002; Lauby-Secretan et al. 2013). They are found in different living organisms due to their tendency to bioaccumulate and bio-magnify in food chains. Humans are exposed to highest PCBs concentrations as they represent the last link of most trophic chains (Hornbuckle and Robertson 2010; Koenig et al. 2012).

Since PCBs have been produced and used worldwide up to 1985, they are found today in all environmental compartments (air, surface and groundwater, soil and sediments). However, due to their semi-volatile and hydrophobic character, PCBs have a tendency to accumulate in soil or sediments, especially those rich in organic matter (Girvin and Scott 1997; Meijer et al. 2003). Soils and sediments are, therefore, the most contaminated compartments. Since natural attenuation of PCBs is very slow (Kastanek et al. 1999), soil remediation is a challenging task.

Several remediation technologies have been developed for PCB-contaminated soils, including biological, physical, thermal and chemical treatments (Gomes et al. 2013); however, safer and more cost effective clean-up strategies are still needed. Among them, chemical methods are of great importance due to their high reactivity against a wide range of contaminants, easy implementation and low energy consumption (Christensen et al. 2009; Al-Shamsi and Thomson, 2013). Numerous studies reported a high efficiency of metallic and bimetallic iron-based nanoparticles for PCB dechlorination in water/alcohol solutions (Chuang et al. 1995; Wang and Zhang 1997; Yak et al. 1999; Lowry and Johnson 2004; Zhu et al. 2011; Fang and Al-Abed 2008). There are, however, few reports on the PCB dechlorination and oxidation in 
soils or sediments, and most of them are focused on spiked soils (He et al. 2009; Quiroga et al. 2009; Rastogi et al. 2009; Tang et al. 2015; Gomez et al. 2015, Fan et al; 2016). Therefore, more investigations are needed to understand the role of soil properties on PCB degradation process in order to improve the efficiency of treatments carried on historically contaminated soils.

The purpose of the present study is to evaluate the ability of Fe-based nanoparticles to promote, firstly, the reduction and then, in further step, the chemical oxidation of PCBs in a historically contaminated soil. While the use of zero-valent iron (ZVI) or bimetallic nanoparticles have been widely investigated for chemical reduction, there is limited information on their use for combined reduction/oxidation approach with the aim to improve the contaminant removal. In this study three approaches of treatment were investigated for PCB degradation in contaminated soils, including i) reductive transformation, ii) direct oxidation and iii) combined reduction/oxidation process. For this aim, ZVI, bimetallic $\mathrm{Fe} / \mathrm{Ni}$ nanoparticles, magnetite and $\mathrm{Ni}$ substituted magnetite were synthesized and characterized. It was reported that the deposition of second passive metal such as $\mathrm{Ni}$ or $\mathrm{Pd}$ on iron surfaces enhances the dechlorination of various organic compounds (Xu et al. 2007; Choi et al. 2008; Grittini et al. 2009; Zhuang et al. 2011; Zhu et Zhang 2011; Zhang et al. 2012). Although $\mathrm{Fe} / \mathrm{Pd}$ is reported to be efficient for rapid dechlorination of PCBs in water (Xe et Zhao 2005; Venkatachalam et al. 2008; Grittini et al. 2009, Yang et al. 2011), $\mathrm{Ni}$ was chosen in this work, as the use of Pd on the large scale may be limited due to its cost.

Experiments were firstly conducted on PCB spiked sand to evaluate the remediation potential of tested approaches away from effects of the soil matrix. Doses of iron nanoparticles and oxidants were varied to assess their impact on PCB degradation 
efficiency. The influence of organic matter content and size of soil fractions was also investigated.

\section{Materials and methods}

\subsection{Chemicals}

Iron sulfate heptahydrate $\left(\mathrm{FeSO}_{4} \cdot 7 \mathrm{H}_{2} \mathrm{O}, 99.5 \%\right)$, sodium borohydride $\left(\mathrm{NaBH}_{4}, 98 \%\right)$ and hydrogen peroxide $\left(\mathrm{H}_{2} \mathrm{O}_{2}, 50 \%\right)$ were purchased from Acros Organics Chemicals, UK. Nickel sulphate heptahydrate $\left(\mathrm{NiSO}_{4} \bullet 7 \mathrm{H}_{2} \mathrm{O}, \geq 95 \%\right)$, ferric chloride hexahydrate $\left(\mathrm{FeCl}_{3} \bullet 6 \mathrm{H}_{2} \mathrm{O}, \geq 99.9 \%\right)$, iron chloride tetrahydrate $\left(\mathrm{FeCl}_{2} \bullet 4 \mathrm{H}_{2} \mathrm{O}, 98 \%\right)$ and potassium persulfate $\left(\mathrm{K}_{2} \mathrm{~S}_{2} \mathrm{O}_{8}, \geq 99.0 \%\right)$ were purchased from Sigma Aldrich, USA. Nickel chloride hexahydrate $\left(\mathrm{NiCl}_{2} \cdot 6 \mathrm{H}_{2} \mathrm{O}, 99 \%\right)$ was purchased from $V W R$ Chemicals, USA. Potassium hydroxide $(\mathrm{KOH}, 85 \%)$ and potassium nitrate $\left(\mathrm{KNO}_{3}\right.$, 99\%) were purchased from Merck KgaA, Germany. Sodium hydroxide (NaOH, 98\%) was provided by Bruchet Dano Rennes Labo, France.

Polychlorobiphenyls (PCB28 (99.9\%); PCB138 (99.5\%); PCB118 (99.6\%) and PCB209 (98\%)) in solid form were purchased from Sigma-Aldrich Co and used without further purification. PCB solutions of 12 congeners (PCB18, PCB28, PCB31, PCB44, PCB52, PCB101, PCB118, PCB138, PCB149, PCB153, PCB180, PCB194) and 17 congeners (PCB33, PCB53, PCB77, PCB 81, PCB105, PCB110, PCB114, PCB118, PCB123, PCB126, PCB149, PCB156, PCB157, PCB167, PCB169, PCB170, PCB189) were analytical grade and purchased from Supelco (Sigma-Aldrich Corporation) and TechLab, France respectively. Hexane (99\%) and methanol (99.9\%) were purchased from Biosolve, France and used as received. Absolute ethanol was purchased from VWR Chemicals. Deionized water was produced by Milli-Q system from Millipore. 
Sand used in this study is Fontainebleau sand with a grain size range of 150-300 $\mu \mathrm{m}$ (mean diameter is $257 \mu \mathrm{m}$ ) obtained from Prolabo.

\subsection{Soil characterization}

The PCB-contaminated soil was provided by INSAVALOR (INSA de Lyon), France. The soil was dried at $40{ }^{\circ} \mathrm{C}$, grinded and passed through $500 \mu \mathrm{m}$ sieve (35 mesh). The obtained fraction was characterized by the Institute en Santé Agro environnement (ISAE) (Combourg, France) and used for soil experiments. Results from soil characterization are presented in Table 1. According to particles size distribution, the soil is classified as silt loam. The soil is carbonated and has a $\mathrm{pH}$ of 7.9. The soil contains $4 \%$ of organic matter and high concentrations of metals ( $42.2 \mathrm{~g}$ $\left.\mathrm{kg}^{-1}\right)$ and exchangeable cations $\left(15.7 \mathrm{~g} \mathrm{~kg}^{-1}\right)$.

The concentrations of identified PCBs in the main fraction (i.e. $<500 \mu \mathrm{m}$ ) and in two separate fractions (F1: $<250 \mu \mathrm{m}$ and F2: $250-500 \mu \mathrm{m}$ ), obtained by sieving (60 mesh) of the main fraction, were determined by GC/MS and are shown in Table 2. The total PCB concentration in all fractions is very high and is above the PCB threshold values for soil established in different countries $\left(<50 \mathrm{mg} \mathrm{kg}^{-1}\right.$ for Canada, New Zealand, Australia and USA) (CCME 1990; Cavanagh 2006; EPA 2009, USEPA 2012). Soils with extremely high PCB concentrations, as in our case, may be considered as hazardous waste (ATSDR 2000). GC/MS analysis showed also the presence of PAHs, including two identified compounds: fluoranthene and pyrene.

\subsection{Synthesis and characterization of nanoparticles}

$\mathrm{The}_{\mathrm{Fe}}{ }^{0}$ and $\mathrm{Fe} / \mathrm{Ni}$ nanoparticles were prepared according to the procedure described elsewhere (Ponder et al. 2000; Schrick et al. 2012). To prepare $\mathrm{Fe}^{0}$ nanoparticles, 
$10.0 \mathrm{~g}$ of $\mathrm{FeSO}_{4} \cdot 7 \mathrm{H}_{2} \mathrm{O}$ was dissolved in $100 \mathrm{~mL}$ methanol/water solution $(30 / 70, \%$ v/v), previously flushed with nitrogen to expel dissolved oxygen. The $\mathrm{pH}$ was adjusted to around 7.0 with $3.8 \mathrm{M} \mathrm{NaOH}$ added drop-wise at a rate of $1.8 \mathrm{~mL} \mathrm{~min}^{-1}$. Then, $3.0 \mathrm{~g}$ of $\mathrm{NaBH}_{4}$ powder was added incrementally to the mixture during 30-35 min. After all $\mathrm{NaBH}_{4}$ is added, the mixture was stirred for 20 min, then filtered through a $0.2 \mu \mathrm{m}$ filter and washed three times with absolute ethanol. $\mathrm{Fe} / \mathrm{Ni}$ nanoparticles were synthesized using the same method. Briefly, $12.3 \mathrm{~g}$ of $\mathrm{FeSO}_{4} \cdot 7 \mathrm{H}_{2} \mathrm{O}$ and $3.0 \mathrm{~g}$ of $\mathrm{NiCl}_{2} \cdot 6 \mathrm{H}_{2} \mathrm{O}$ were dissolved in $100 \mathrm{~mL}$ methanol/water solution $(30 / 70, \% \mathrm{v} / \mathrm{v})$. After the $\mathrm{pH}$ was adjusted to $6.5-7.0,5.0 \mathrm{~g}$ of $\mathrm{NaBH}_{4}$ was added incrementally during 50-55 min. The obtained solid filtered through $0.2 \mu \mathrm{m}$ filter, washed one time with degassed water and twice with absolute ethanol.

The magnetite nanoparticles $\left(\mathrm{Fe}_{3} \mathrm{O}_{4}\right)$ were prepared by the method described by Usman et al. (2012a). The reaction was carried in $250 \mathrm{~mL}$ nalgene bottle with a strong stream of nitrogen to avoid air oxidation. Firstly, $2.57 \mathrm{~g}$ of ferrihydrite was added to $225 \mathrm{~mL}$ of deionized water. The mixture was stirred by nitrogen stream for $10 \mathrm{~min}$ before $3.7 \mathrm{~g}$ of $\mathrm{FeSO}_{4} \cdot 7 \mathrm{H}_{2} \mathrm{O}$ was dissolved in the mixture. Then $1 \mathrm{M} \mathrm{NaOH}$ was added to provide the $\mathrm{n}\left(\mathrm{OH}^{-}\right) / \mathrm{n}\left(\mathrm{Fe}^{3+}\right)$ ratio equal to 1 . The nalgene bottle was closed and was stirred (200 rpm) for $72 \mathrm{~h}$. The obtained solid was centrifuged and washed once with degassed water and twice with absolute ethanol. The method used for preparation of nanoparticles of Ni-substituted magnetite $\left(\mathrm{Fe}_{3-\mathrm{x}} \mathrm{Ni}_{\mathrm{x}} \mathrm{O}_{4}\right)$ was based on procedures described earlier by David and Welch (1956) and Sidhu et al (1978). For this purpose, $46.91 \mathrm{~g}$ of $\mathrm{FeSO}_{4} \cdot 7 \mathrm{H}_{2} \mathrm{O}$ and $3.16 \mathrm{~g}$ of $\mathrm{NiSO}_{4} \cdot 7 \mathrm{H}_{2} \mathrm{O}$ were dissolved in $350 \mathrm{~mL}$ of deionized water previously flushed with nitrogen. Solution was boiled and alkaline solution $\left(4.04 \mathrm{~g}\right.$ of $\mathrm{KNO}_{3}$ and $28.05 \mathrm{~g}$ of $\mathrm{KOH}$ dissolved in $120 \mathrm{~mL}$ of deionized water) was added drop-wise at a rate of $4.5 \mathrm{~mL} \mathrm{~min}^{-1}$. After all alkaline 
solution was added, the mixture was boiled for additional $30 \mathrm{~min}$, then cooled and centrifuged. The black precipitate was washed several times with deionized water and then with absolute ethanol.

All obtained solids were vacuum-dried at room temperature for $48 \mathrm{~h}$ and then grinded to obtain a powder.

Firstly, the X-ray diffractogramms (not shown) have confirmed the nature of obtained precipitates. The particles were then characterized by transmission electron microscopy (TEM) (JEOL JSM 6400). The BET surface area of particles was determined by nitrogen adsorption (Autosorb - 1, Quantachrome Instruments). The elemental composition and composition of the outermost surface of particles were also analyzed by energy-dispersive X-ray spectroscopy (EDS) and X-ray photoelectron spectrometry (XPS), respectively.

\subsection{Experimental setup for remediation experiments}

The efficiency of synthesized iron nanoparticles $\left(\mathrm{Fe}^{0}, \mathrm{Fe} / \mathrm{Ni}, \mathrm{Fe}_{3} \mathrm{O}_{4}, \mathrm{Fe}_{3-\mathrm{x}} \mathrm{Ni}_{\mathrm{x}} \mathrm{O}_{4}\right)$ was evaluated in following remediation systems: i) reductive dechlorination, ii) $\mathrm{H}_{2} \mathrm{O}_{2}$ oxidation, iii) persulfate oxidation, iv) reduction $+\mathrm{H}_{2} \mathrm{O}_{2}$ oxidation and v) reduction + persulfate oxidation (Table 3). Experiments were performed in spiked sand and historically contaminated soil.

To obtain spiked sand $\left(5 \mu \mathrm{g} \mathrm{g}^{-1}\right), 1 \mathrm{~mL}$ of PCB solution $\left(10 \mu \mathrm{g} \mathrm{mL}^{-1}\right.$ of PCB28 or PCB118 in hexane) was dispersed on $2 \mathrm{~g}$ of pure sand and solvent was evaporated in the hood at room temperature. Soil experiments were carried on $2 \mathrm{~g}$ of main fraction $(<500 \mu \mathrm{m})$ of soil.

In typical experiment, metallic nanoparticles were added and homogenized with the sand/soil by magnetic stirring. In reductive transformation step, 2-3 $\mathrm{mL}$ of deionized 
water was added to start reaction (stirring speed $400 \mathrm{rpm}$ ) and the flask was closed to avoid water evaporation. In chemical oxidation experiments, the oxidant was dissolved in water $(2-3 \mathrm{~mL})$ before being added to the sand/soil. The water volume varied with the amount of metallic nanoparticles added to provide solid/liquid (S/L) ratio of $1 / 1$. In the case of combined approach $\left(4^{\text {th }}\right.$ and $5^{\text {th }}$ system), oxidants (persulfate in solid form and $\mathrm{H}_{2} \mathrm{O}_{2}, 50 \%$ w/w) were added directly to the reaction mixture after $24 \mathrm{~h}$ of reaction with iron nanoparticles. Experiments were performed without adjustment of $\mathrm{pH}$ (sand: $\mathrm{pH}_{\mathrm{t}=0}=7.2 \pm 0.3$, soil: $\mathrm{pH}_{\mathrm{t}=0}=8.2 \pm 0.3$ ). The $\mathrm{pH}$ remained almost constant along the reaction for all investigated approaches. Blanks were carried out without addition of metallic nanoparticles.

In experiments with ethanol or cyclodextrin, $2 \mathrm{~mL}$ of absolute ethanol or cyclodextrin solution $(0.05$ or $0.10 \mathrm{M}$ in water) was added to soil and stirred during $24 \mathrm{~h}$ before being mixed with metallic particles.

\subsection{PCB extraction and analysis}

Prior to analysis, the soil was freeze-dried in order to avoid volatilization of PCBs. Then, the soil was grinded with a spatula and transferred in the ASE (Accelerated Solvent Extractor, Dionex ASE 300) cells for extraction. Extraction was carried in three cycles at $135^{\circ} \mathrm{C}$ and 1500 Bars using hexane as a solvent. Round bottom flask was filled with $10 \mathrm{~mL}$ of hexane and extracted in an ultrasonic bath during $20 \mathrm{~min}$ to recover PCBs from soil dust remaining in the flask. Two extracts (from ASE and ultrasonic bath) were combined and concentrated to around $5 \mathrm{~mL}$ by rotary evaporation. The obtained supernatant was concentrated to $2 \mathrm{~mL}$ with a help of gentle stream of pure nitrogen. Then, internal standard (PCB209) was added and solution was filtered and transferred to a glass vial for analysis. 
In order to assess the recovery of different congeners from the historically contaminated soil, surrogate standards were added to soil samples. We have chosen 3 PCBs $\left({ }^{13} \mathrm{C}\right.$ labeled PCB28, ${ }^{13} \mathrm{C}$ labeled PCB118, ${ }^{13} \mathrm{C}$ labeled PCB180), to assess the recovery of PCBs of different chlorination grade. These results showed that the lower-chlorinated congener $\left({ }^{13} \mathrm{C}\right.$ labeled PCB28) had the lowest recovery (i.e. $\left.81 \%\right)$, while 101 and $95 \%$ were obtained for PCB118 and PCB180, respectively. This suggests that volatile compounds (mono-, di- and trichlorobiphenyls) may be lost during evaporation step.

The PCBs from the sand were extracted by liquid-liquid extraction using hexane as a solvent. $2 \mathrm{~mL}$ of hexane was added to the reaction mixture and PCBs were extracted in ultrasonic bath during $20 \mathrm{~min}$. The extraction was repeated 2 times, removing every time $1 \mathrm{~mL}$ of extract and adding $1 \mathrm{~mL}$ of pure hexane. The extracts were combined and concentrated to $2 \mathrm{~mL}$ by gentle stream of pure nitrogen and internal standard was added before analysis. The extraction efficiencies were $93 \%$ and $96 \%$ for PCB28 and PCB118, respectively.

The PCB analysis was performed on gas chromatograph (Perkin Elmer, model Clarus 500) equipped with an ion trap mass spectrometer using the splitless mode (injection volume: $2 \mu \mathrm{L}$ ). Chromatographic separations were achieved on a DB5-MS column $(60 \mathrm{~m} \times 0.25 \mathrm{~mm}$, film thickness: $0.25 \mu \mathrm{m})$ that was eluted with helium at

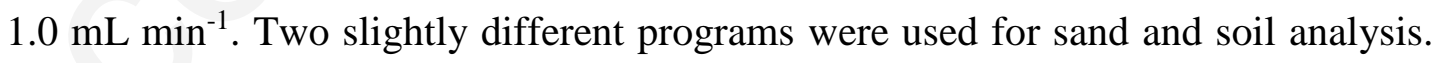
In both cases, after an initial hold for $2 \mathrm{~min}$ at $140{ }^{\circ} \mathrm{C}$, the temperature was ramped to $200{ }^{\circ} \mathrm{C}$ at $20{ }^{\circ} \mathrm{C} \min ^{-1}$ and to $320{ }^{\circ} \mathrm{C}$ at $3{ }^{\circ} \mathrm{C} \min ^{-1}\left(10{ }^{\circ} \mathrm{C} \min ^{-1}\right.$ in the case of sand $)$, then held for 4 min before cool down. An on-column injection was performed and the injector and transfer line were maintained at $300{ }^{\circ} \mathrm{C}$. Mass spectra were recorded 
in the SIR (selected ion recording) mode. PCBs were identified by comparing of their retention times with those of authentic standards.

\section{Results and discussion}

\subsection{Characterization of iron nanoparticles}

According to TEM images, the synthetic Fe-based particles $\left(\mathrm{Fe}^{0}, \mathrm{Fe} / \mathrm{Ni}, \mathrm{Fe}_{3} \mathrm{O}_{4}, \mathrm{Fe}_{3}-\right.$ ${ }_{x} \mathrm{Ni}_{\mathrm{x}} \mathrm{O}_{4}$ ) are spherical (Fig. 1). $\mathrm{Fe} / \mathrm{Ni}$ and $\mathrm{Fe}^{0}$ nanoparticles are aggregated in form of chains, which has been attributed to magnetic interactions between adjacent metallic particles (Lowry and Johnson 2004; Sun et al. 2006b; Zhang et al. 2012; Schrick et al. 2012), as well as to the natural tendency of these particles to remain in the most thermodynamically stable state (Cushing et al. 2004; Kanel et al. 2006). TEM images of nanoparticles (Fig. 1) were also used to evaluate the particle size of solids (Table 4). The surface area of bimetallic particles is higher than that of the particles of ZVI (Table 4). This is consistent with previous studies, where increase in Ni content led to the increase in the surface area of bimetallic particles (Feng et al. 2005; Hong et al. 2009; Schrick et al. 2012). The elemental composition (Table 5) and composition of the surface (Table 6) of particles were analyzed by EDS and XPS. The comparison of two compositions shows that $\mathrm{Fe}^{0}$ and $\mathrm{Fe} / \mathrm{Ni}$ particles have an external layer enriched with oxygen. The XPS also indicates the presence of boron, sulfur and sodium impurities on the surface of particles left from synthesis process. Infrared spectroscopy analysis was carried out on magnetite to identify the nature of needlelike particles observed on TEM images. The two peaks, $796.5 \mathrm{~cm}^{-1}$ and $891.0 \mathrm{~cm}^{-1}$, correspond to the infrared bands of goethite $\left(\tau \mathrm{OH}=795 \mathrm{~cm}^{-1}\right.$ and $\left.\delta \mathrm{OH}=892 \mathrm{~cm}^{-1}\right)$ (Schwertmann et Cornell 2000). Generally, the total iron content in the natural 
magnetite varies from around $68 \%$ to $71 \%$, and from $69 \%$ to $72 \%$ for commercial particles (Salazar-Camacho et al. 2013). Lower iron content, as in our case, can be explained by the presence of goethite, adsorbed water and other impurities on the surface of particles (Yu et al. 2006).

\subsection{PCB removal in a spiked sand}

The $\mathrm{Fe}^{0}$-induced reductive dechlorination was already reported to be efficient method for PCB degradation (Korte et al. 2002; Sun et al. 2006a; Aristov and Habekost, 2010). The reductive dechlorination process using ZVI passes through direct electron transfer (Eq. 1) from $\mathrm{Fe}^{0}$ to $\mathrm{PCB}$ (represented here as $\mathrm{RCl}$ ):

$$
\mathrm{Fe}^{0}+\mathrm{RCl}+\mathrm{H}^{+} \rightarrow \mathrm{Fe}^{\mathrm{II}}+\mathrm{RH}+\mathrm{Cl}^{-}
$$

The generated $\mathrm{Fe}^{\mathrm{II}}$ can also contribute to PCB dehalogenation when adsorbed on oxide coating layer of ZVI, but it can be quickly oxidized by $\mathrm{O}_{2}$ under aerobic conditions (Sung et al. 2005; Keenan et al. 2008; Katsoyiannis et al. 2008; Ramos et al. 2009). On the other hand, the anaerobic corrosion of $\mathrm{Fe}^{0}$ produces ferrous ion (Eq. 2), whereas the aerobic corrosion generates ferrous ion and $\mathrm{HO}^{-}$(Eq. 3) or ferrous ion and $\mathrm{H}_{2} \mathrm{O}_{2}$ at acidic $\mathrm{pH}$ (Eq. 4).

$$
\begin{aligned}
& \mathrm{Fe}^{0}+2 \mathrm{H}_{2} \mathrm{O} \rightarrow \mathrm{Fe}^{\mathrm{II}}+2 \mathrm{OH}^{-}+\mathrm{H}_{2} \\
& \mathrm{Fe}^{0}+1 / 2 \mathrm{O}_{2}+\mathrm{H}_{2} \mathrm{O} \rightarrow \mathrm{Fe}^{\mathrm{II}}+2 \mathrm{OH}^{-} \\
& \mathrm{Fe}^{0}+\mathrm{O}_{2}+2 \mathrm{H}^{+} \rightarrow \mathrm{Fe}^{\mathrm{II}}+\mathrm{H}_{2} \mathrm{O}_{2} \\
& \mathrm{Fe}^{0}+\mathrm{H}_{2} \mathrm{O}_{2}+2 \mathrm{H}^{+} \rightarrow \mathrm{Fe}^{\mathrm{II}}+2 \mathrm{H}_{2} \mathrm{O} \\
& \mathrm{Fe}^{\mathrm{II}}+\mathrm{H}_{2} \mathrm{O}_{2} \rightarrow \mathrm{Fe}^{\mathrm{III}}+\mathrm{OH}^{-}+\mathrm{OH}^{-}
\end{aligned}
$$


The generated $\mathrm{H}_{2} \mathrm{O}_{2}$ can then react at acidic $\mathrm{pH}$ with $\mathrm{Fe}^{0}$ (Eq. 5), and/or with $\mathrm{Fe}^{\mathrm{II}}$ to produce $\mathrm{OH}^{\bullet}$ (Eq. 6), but this process remains negligible, especially in soil slurry (i.e. circumneutral $\mathrm{pH})$. For this reason, addition of oxidant at that stage could be an efficient way to produce a high amount of radical species that could achieve complete degradation and mineralization of the target contaminants (Zha et al. 2014). Indeed, the added oxidant $\left(\mathrm{H}_{2} \mathrm{O}_{2}\right.$ or persulfate $)$ could react with $\mathrm{Fe}^{\mathrm{II}}$ adsorbed on oxide coating of ZVI to generate reactive oxygen species (ROS) as following:

$$
\begin{aligned}
& \mathrm{Fe}-\mathrm{Fe}^{\mathrm{II}}+\mathrm{H}_{2} \mathrm{O}_{2} \rightarrow \mathrm{Fe}-\mathrm{Fe}^{\mathrm{III}}+\mathrm{OH}^{-}+\mathrm{OH}^{\cdot} \\
& \mathrm{Fe}-\mathrm{Fe}^{\mathrm{II}}+\mathrm{S}_{2} \mathrm{O}_{8}^{2-} \rightarrow \mathrm{Fe}-\mathrm{Fe}^{\mathrm{III}}+\mathrm{SO}_{4}^{-\bullet}+\mathrm{SO}_{4}^{2-}
\end{aligned}
$$

Formed $\mathrm{Fe}^{\mathrm{III}}$ precipitates as a coating layer of ZVI leading to the passivation of the surface (Eq. 7 and 8). The nature of the coating may depend on $\mathrm{pH}$, solution chemistry and type of ZVI. Under acidic conditions, magnetite $\left(\mathrm{Fe}_{3} \mathrm{O}_{4}\right)$, goethite (a$\mathrm{FeOOH})$ and hematite $\left(\mathrm{a}-\mathrm{Fe}_{2} \mathrm{O}_{3}\right)$ have been detected as the major oxidation byproducts ( $\mathrm{Li}$ and Whang 2006; Luo et al. 2010). The passivation of ZVI surface is also observed during the reduction of contaminants even in anoxic environments, and is often encountered in oxidation reactions due to the utilization of strong oxidants.

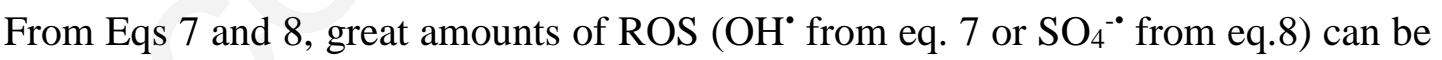
generated, which could oxidize and then mineralize the target contaminants.

In the following paragraphs, the efficiency of synthetic iron nanoparticles to promote 1) reductive transformation, 2) direct oxidation or 3) combined reduction/oxidation process, was tested in PCB-spiked sand. The PCB concentration from the blank test $\left(4.9 \mu \mathrm{g} \mathrm{g}^{-1}\right)$ was considered as $\mathrm{C}_{0}$. 
Reductive transformation. As shown in Fig. 2A, bimetallic nanoparticles of Fe/Ni showed the highest degradation extent in reductive transformation (97\% for PCB28 and $79 \%$ for PCB118), while only $49 \%$ of PCB28 and $31 \%$ of PCB118 were removed with $\mathrm{Fe}^{0}$. No significant decrease in $\mathrm{PCBs}$ concentration was, however, obtained with $\mathrm{Fe}_{3} \mathrm{O}_{4}$ or $\mathrm{Fe}_{3-\mathrm{x}} \mathrm{Ni}_{\mathrm{x}} \mathrm{O}_{4}$. As expected for reductive dechlorination reactions, the PCB degradation extents increased with particle dose increasing for both bimetallic $\mathrm{Fe} / \mathrm{Ni}$ and $\mathrm{Fe}^{0}$ nanoparticles (from 0.125 to $0.5 \mathrm{~g} \mathrm{~g}^{-1}$ sand) (Fig. 2B). Both PCB28 and PCB118 are ortho-substituted congeners, which are known to be less reactive than their nonortho-substituted homologues (Lowry and Johnson, 2004). In all experiments the low-chlorinated congener PCB28 showed slightly higher degradation extents than PCB118. It was reported that the dechlorination rate of PCBs in water/alcohol solutions increased with increasing chlorination degree (Yak et al., 1999; Lowry and Johnson, 2004). However, no such structure-reactivity relationship has been observed in the soil systems. It should be noted that traces of biphenyl have been detected, but the mass balance could not be achieved as the concentrations were too low (i.e. < Q.L.). The formation of PCB28 and PCB31 were also detected during the reaction of $\mathrm{PCB} 118$ with $\mathrm{Fe} / \mathrm{Ni}$ nanoparticles, but the concentrations were too low to be quantified. Since low-chlorinated PCBs or biphenyl are relatively volatile, they may be lost during the evaporation step (See section 2.5).

Chemical oxidation. Chemical oxidation of PCBs using $\mathrm{H}_{2} \mathrm{O}_{2}$ and persulfate was carried out in presence of $\mathrm{Fe}^{0}$ and magnetite nanoparticles. Only $\mathrm{Fe}^{0}$ and magnetite were used here, due to their efficiency in Fenton-like based oxidation as previously 
reported (Matta et al. 2007; Hanna et al. 2008; Liang and Lai 2009). In the case of $\mathrm{H}_{2} \mathrm{O}_{2}$ oxidation, degradation extents of PCB28 and PCB118 reached $90 \%$ and $49 \%$ in presence of $\mathrm{Fe}^{0}$, and $77 \%$ and $69 \%$ in the presence of $\mathrm{Fe}_{3} \mathrm{O}_{4}$ (Fig. 3A, B). Higher degradation extents of PCB28 and PCB118 were obtained in persulfate oxidation, i.e. $99 \%$ and $79 \%$ in presence of $\mathrm{Fe}^{0}$, and $99 \%$ and $90 \%$ in presence of $\mathrm{Fe}_{3} \mathrm{O}_{4}$, respectively. Similar results were reported by Quiroga et al. (2009), where more than $85 \%$ of PCBs were degraded by Fenton oxidation in PCB-spiked glass beads, but by using soluble $\mathrm{Fe}^{3+}$ instead of Fe-solid. As in the present work, higher degradation efficiencies were observed for low-chlorinated congeners $(64 \%$ for pentachlorobiphenyls vs. $97 \%$ for trichlorobiphenyls). Because hydroxyl substitutions generally occur at non-halogenated positions, lower-chlorinated PCBs are more reactive in advanced oxidation processes (Sedlak et Andren, 1991; Quiroga et al. 2009).

Combined approach. The combined approach was evaluated in the same experimental setup but by adding the oxidant $\left(\mathrm{H}_{2} \mathrm{O}_{2}\right.$ or $\left.\mathrm{K}_{2} \mathrm{~S}_{2} \mathrm{O}_{8}\right)$ after a preliminary reduction step ( $24 \mathrm{~h}$ ). $\mathrm{Fe}^{0}$ nanoparticles showed lower degradation extents than those obtained in direct oxidation (88\% and $31 \%$ with $\mathrm{H}_{2} \mathrm{O}_{2}$ and $97 \%$ and $48 \%$ with persulfate). However, magnetite particles exhibited similar degradation extents as in the case of direct oxidation by removing $83 \%$ and $57 \%$ of PCB28 and PCB118 with $\mathrm{H}_{2} \mathrm{O}_{2}$, and almost $100 \%$ and $89 \%$ with $\mathrm{K}_{2} \mathrm{~S}_{2} \mathrm{O}_{8}$, respectively (Fig. 3C). Decreased efficiency of $\mathrm{Fe}^{0}$ after a preliminary reduction step may be explained by the surface passivation of $\mathrm{Fe}^{0}$ particles (O'Carroll et al. 2013). In contrast, similar degradation extents in direct oxidation and combined approach were observed for magnetite, indicating its high catalytic stability. Comparatively to reduction experiments, 
PCB28 showed higher degradation extent than PCB118. However, no by-products can be detected, probably due to their low concentrations in the investigated system. Consequently, we used only the PCB degradation percentage as an indicator to evaluate the efficiency of investigated methods.

These experiments aimed to assess the capacity of iron-based nanoparticles to degrade PCBs in spiked sand away from the soil matrix effect. In the following section, the ability of Fe-particles to induce chemical reduction and then promote Fenton reactions in a historically contaminated soil was investigated.

\subsection{PCB degradation in a historically contaminated soil}

The PCB concentrations from blank tests were considered as reference concentrations of congeners $\left(\mathrm{C}_{0}\right)$. Only PCBs identified in the blank tests were quantified.

Reductive transformation. $\mathrm{Fe}^{0}$ and $\mathrm{Fe} / \mathrm{Ni}$ particles showed the highest degradation extents (14\% and $18 \%$ respectively), given the relative error in total concentration $( \pm 5 \%)$ (Fig.4A, B). No significant degradation $(<6 \%)$ was observed in presence of magnetite and Ni-substituted magnetite. The dechlorination was supposed to take place in the first $24 \mathrm{~h}$, as similar degradation extents were obtained for 48 and $240 \mathrm{~h}$. This may result from (i) the passivation of $\mathrm{Fe}^{0}$ particles in soil slurry and/or (ii) the less availability of PCBs in soil (i.e. only a small part can react with reactive particles) (O'Carroll et al. 2013; Jarovska 2008). The increase in particles dose from

0.25 to $0.50 \mathrm{~g} \mathrm{~g}^{-1}$ (w/w) of soil slightly improved the degradation extents, e.g. from 14 to $17 \%$ for $\mathrm{Fe}^{0}$ and from 18 to $26 \%$ for $\mathrm{Fe} / \mathrm{Ni}$ (Fig.4C). 
Several experiments were conducted using Fe/Ni nanoparticles (the most efficient for reductive dechlorination) to determine the effect of $\mathrm{pH}$ on the efficiency of reductive transformation of PCBs. Varying pH from 8.5 to 4.0 did not affect the total PCB removal (18\% vs. 16\%), which is in agreement with previous published work (Varanasi et al. 2007). The addition of methyl- $\beta$-cyclodextrin and ethanol to enhance the solubility and availability of PCBs did not affect the overall PCB degradation extent $(\sim 15 \%$ with cyclodextrin and $\sim 12 \%$ with ethanol $v s .18 \%$ without). The impact of enhancement-solubility agents is strongly related to the nature of soil and speciation/localization of contaminants (Viglianti et al., 2006). While Varanasi et al. (2007) showed no impact of surfactant addition on PCB degradation in soil, a recent work reported an increase in the electrochemically-assisted removal of PCBs in soil using saponin and Tween 80 (Gomes et al. 2014). Furthermore, the carboxymethyl- $\beta$ cyclodextrin (Lindsey et al. 2003) and ethanol (Maloney et al. 2011) have been reported earlier to enhance the hydrodechlorination of PCBs in water.

The limited efficiency of metallic nanoparticles in contaminated soil may be also explained by the presence of other contaminants such as PAHs and heavy metals. Soil constituents, including soil organic matter (SOM) can also limit the degradation of organic pollutants by reductive transformation and/or chemical oxidation (Waisner et al. 2008; Jarovska et al. 2008; Usman et al. 2012c). Indeed, PCBs may strongly bound with organic matter and/or clay in the soil, which make them less available for chemical reactions as previously reported for PAHs (Kawahara et al. 1995).

As observed in the sand system, traces of low chlorinated compounds were detected, but could not be quantified due to their low amounts. Since high chlorinated compounds can be transformed into lower-chlorinated compounds (already presented in the soil), a slight increase of concentration of low-chlorinated PCBs along the 
reaction was observed (PCB18, 31, 28). In addition to a number of analytical limitations to quantify unknown products, possible loss of volatile compounds (i.e. low-chlorinated ones) during the concentration/evaporation step may explain the quantification issue, as it was observed for the ${ }^{13} \mathrm{C}$ labeled PCB28 used as a surrogate (see section 2.5.).

Direct oxidation. In oxidation tests using synthesized nanoparticles as catalysts, slightly higher degradation extents were observed (Fig. 5A, B). $\mathrm{H}_{2} \mathrm{O}_{2}$ oxidation resulted in the degradation of $18 \%, 19 \%, 7 \%$ and $7 \%$ of $\mathrm{PCBs}$ for $\mathrm{Fe}^{0}, \mathrm{Fe} / \mathrm{Ni}, \mathrm{Fe}_{3} \mathrm{O}_{4}$ and $\mathrm{Fe}_{3-\mathrm{x}} \mathrm{Ni}_{\mathrm{x}} \mathrm{O}_{4}$, respectively after $48 \mathrm{~h}$. Comparable degradation extents were observed in persulfate oxidation $\left(13 \%, 18 \%, 8 \%\right.$ and $10 \%$, for $\mathrm{Fe}^{0}, \mathrm{Fe} / \mathrm{Ni}, \mathrm{Fe}_{3} \mathrm{O}_{4}$ and $\mathrm{Fe}_{3-\mathrm{x}} \mathrm{Ni}_{\mathrm{x}} \mathrm{O}_{4}$, respectively). It is worth noting that magnetite nanoparticles, which did not show any reductive transformation capacity, showed 7-8\% of PCBs degradation in direct oxidation. Similarly to spiked sand, persulfate oxidation showed higher degradation efficiency than $\mathrm{H}_{2} \mathrm{O}_{2}$ oxidation. Degradation extents of PCBs in blank oxidation tests did not exceed $4 \%$ for both oxidants $\left(\mathrm{H}_{2} \mathrm{O}_{2}, \mathrm{~K}_{2} \mathrm{~S}_{2} \mathrm{O}_{8}\right)$, suggesting that endogenous soil constituents cannot activate the oxidation reaction.

Combined approach. In the case of addition of an oxidant after $24 \mathrm{~h}$ of reduction reaction (i.e. combined approach), the overall degradation extents did not change in comparison with those obtained in direct oxidation (Fig. 5C).

Attempts to identify and then quantify the degradation by-products failed due to their low concentration in soil. However, the nature of by-products should be quite different with respect to the investigated degradation reaction. In the case of reductive transformation, formation of lower-chlorinated PCBs or biphenyl is 
expected (Wang and Zhang 1997; Fang and Al-Abed 2008; Zhang et al. 2012), while the oxidation of PCBs gives a variety of more complex by-products including ringopened compounds (Anitescu and Tavlaride, 2005).

Effect of oxidant dose on PCB degradation. The effect of oxidant concentration was also investigated in order to improve the degradation efficiency of PCBs. Magnetite was used as a catalyst due to its high catalytic stability (Xue et al. 2009). The increase in concentration of $\mathrm{K}_{2} \mathrm{~S}_{2} \mathrm{O}_{8}$ from $45 \mathrm{mM}$ (dose 1) to $180 \mathrm{mM}$ (dose 3) did not improve significantly the overall PCB degradation, i.e. from $8 \%$ to $11 \%$ (Fig. 6). There was no difference in degradation extents (10\% and 8\%) obtained for two $\mathrm{H}_{2} \mathrm{O}_{2}$ concentrations $(0.2 \mathrm{M}$ and $2.0 \mathrm{M})$. However, the highest degradation extent $(21 \%)$ was observed for the concentration of $1 \mathrm{M}$ (dose 2) of $\mathrm{H}_{2} \mathrm{O}_{2}$. Decrease in degradation efficiency at higher $\mathrm{H}_{2} \mathrm{O}_{2}$ concentration can be explained by the scavenging effect of hydroxyl radical, as previously reported for Fenton-like reactions (Wu et al. 2006; Xue et al. 2009). At much higher concentration of $\mathrm{H}_{2} \mathrm{O}_{2}$ the $\mathrm{HO}^{\circ}$ radical reacts with $\mathrm{H}_{2} \mathrm{O}_{2}$ rather than PCBs. Other concentrations of hydrogen peroxide were tested using $\mathrm{Fe}^{0}$ and magnetite nanoparticles, but the overall degradation did not exceed $21 \%$. This lack in treatment efficiency even at high oxidant doses let us suppose that chemical and/or physical limitations may exist in the case of historically contaminated soil. These limitations may be attributed to soil composition such as organic matter and clay, chemical unavailability of PCBs and presence of cocontaminants as competitors or scavengers (e.g. metals and PAH in the present study) (Andy Hong et al. 2008). It was reported that the degradation efficiency of PCBs and other pollutants is inversely proportional to the content of soil organic matter (SOM) (Flotron et al. 2005; Goi and Trapido 2004; Tang et al. 2015). In the 
case of oxidation reactions, the competition between SOM and organic pollutants for the chemical oxidant may occur, i.e. scavenging of $\mathrm{HO}^{\circ}$ or $\mathrm{SO}_{4}^{-\circ}$ radicals by organic matter (Jonsson et al. 2007). Additionally, in the case of multi-contaminated soil, metals and other organic pollutants may consume the added oxidant before it has opportunity to react with PCBs. Therefore, because of presence of SOM and PAHs, large amount of radical species is required to oxidize target compounds (Jarovska et al. 2008; Waisner et al. 2008). Furthermore, oxidation of SOM may modify their outer surface and create hydrophilic sites which can thus reduce the sorptive capacity of pollutants (Romero et al. 2011). The high reactivity of radicals with soil constituents, called as natural oxidant demand of soil, may explain the low efficiency of oxidation reaction in real contaminated soils (Usman et al. 2012c).

Effect of soil matrix on PCB degradation. In order to evaluate the impact of soil constituents on oxidation efficiency of PCBs, experiments were conducted on extractable organic matter (EOM) from contaminated soil. For that, organic extract from $2 \mathrm{~g}$ of soil (fraction $\leq 500 \mu \mathrm{m}$ ) was dispersed homogeneously on $2 \mathrm{~g}$ of pure sand and solvent was evaporated at room temperature. The obtained PCB concentration was equal to $\mathrm{PCB}$ concentration in soil (i.e. $\sim 450 \mathrm{mg} \mathrm{kg}^{-1}$ ).

The oxidation experiment was then carried out on obtained spiked sand and contaminated soil using magnetite as catalyst (Fig. 7). The degradation extent of PCBs in spiked sand increased from $16 \%$ to $27 \%$ due to increase in $\mathrm{H}_{2} \mathrm{O}_{2}$ amount added from $0.2 \mathrm{M}$ to $2.0 \mathrm{M}(10 \times 0.2 \mathrm{M})$, but does not change significantly (from $5 \%$ to $8 \%$ ) in the case of contaminated soil (Fig. 7).

Higher PCBs degradation extent in spiked sand highlights the role of insoluble organic matter and other soil mineral fractions in decrease in oxidation efficiency, as 
earlier observed for PAH in our previous work (Usman et al. 2012c). These components could compete with organic pollutants and thus can deplete the oxidant (Bogan and Trbovic 2003; Flotron et al. 2005). Another reason behind this higher oxidation efficiency could be the higher pollutant availability in spiked sand as compared to the contaminated soil. Previous works reported that availability and ultimate degradation extent of PAH were significantly enhanced after extraction pretreatment of PAH-contaminated soils (Usman et al. 2012c).

\subsection{PCB removal in different soil particle-size fractions}

In order to evaluate the PCB degradation efficiency with respect to the soil particlesize fraction, reductive transformation experiments were carried out for two different fractions: F1 $(<250 \mu \mathrm{m})$ and F2 $(250-500 \mu \mathrm{m})$, and compared with the data obtained for the whole fraction $\mathrm{F}(<500 \mu \mathrm{m})$. The PCB concentration in the finest fraction $\mathrm{F} 1$ $(<250 \mu \mathrm{m})$ is more than two times higher than that in the fraction F2 $(250-500 \mu \mathrm{m})$ (Table 2). The results showed that the dechlorination extent was limited for the fine fraction $(<250 \mu \mathrm{m})$ using $\mathrm{Fe}^{0}$ or $\mathrm{Fe} / \mathrm{Ni}$ particles. However, there was no significant difference $(<3 \%)$ in PCB degradation for F2 $(250-500 \mu \mathrm{m})$ and $\mathrm{F}(<500 \mu \mathrm{m})$. In the case of degradation using $\mathrm{Fe}^{0}$, degradation extents of total PCBs were $2 \%, 13 \%, 12 \%$ for fractions $<250 \mu \mathrm{m}, 250-500 \mu \mathrm{m}$ and $<500 \mu \mathrm{m}$, respectively (Fig. 8). In the case of degradation with bimetallic nanoparticles, degradation extents for total PCBs were $2 \%, 16 \%$ and $17 \%$ for the same fractions. The limited efficiency in the fine fraction may be explained by its higher SOM content (about 2-times higher than in F), which is in accordance with previous works (Flotron et al. 2005; Goi and Trapido 2004). PCBs in the finest fraction are probably less available for degradation due to their strong interactions with organic matter (Bogan and Trbovic, 2003). 


\section{Conclusions}

The experiments on spiked sand showed that metallic particles of $\mathrm{Fe}^{0}$ and $\mathrm{Fe} / \mathrm{Ni}$ are efficient for $\mathrm{PCB}$ reductive transformation, whereas bimetallic particles $\mathrm{Fe} / \mathrm{Ni}$ showed the highest degradation extent (i.e. 88\%). Magnetite and Ni-substituted magnetite did not show reduction efficiency even for low PCB concentrations in spiked sand. Despite the fact that $\mathrm{Fe}^{0}$ nanoparticles are less reactive that bimetallic nanoparticles for reductive transformation, they exhibited high reactivity in oxidation reaction using $\mathrm{H}_{2} \mathrm{O}_{2}$ or $\mathrm{K}_{2} \mathrm{~S}_{2} \mathrm{O}_{8}$. Magnetite nanoparticles show comparable degradation efficiency in oxidation reaction and can be more efficient than $\mathrm{Fe}^{0}$ particles due to their higher stability. As expected, degradation extents observed for PCB28 were higher than those obtained for PCB118.

The experiments on contaminated soil showed that degradation efficiency was strongly affected by soil properties. Comparatively to spiked sand, bimetallic particles $\mathrm{Fe} / \mathrm{Ni}$ showed the highest degradation extent in reductive transformation of $\mathrm{PCB}$, but with a limited reactivity (i.e. 18\%). The double dose of particles improved the $\mathrm{PCB}$ degradation efficiencies from $18 \%$ to $26 \%$ for $\mathrm{Fe} / \mathrm{Ni}$, and $14 \%$ to $17 \%$ for $\mathrm{Fe}^{0}$. Bimetallic nanoparticles are much more efficient for $\mathrm{PCB}$ dechlorination that $\mathrm{Fe}^{0}$ nanoparticles, but in the case of historically contaminated soil this difference was less pronounced due to limitations caused by soil composition. Oxidation reactions showed higher PCBs degradation extents. However, overall degradation extents obtained with different types of treatment did not exceed 30\%, suggesting that only a small part of PCBs in soil was available for reaction with catalyst and/or oxidant. The degradation efficiency was found to be strongly affected by organic matter 
content. No significant difference between lower and higher chlorinated PCBs was observed in soil in terms of degradation extent.

When oxidant was added after a preliminary reduction step, mineralization of the reduction by-products could occur, as the radical species would likely react with lowchlorinated compounds or biphenyl, rather than with more stable high-chlorinated compounds. This approach may improve the overall degradation and minimize the formation of toxic metabolites. Although high degradation extents of PCBs were not achieved in the investigated contaminated soil, this work provides new insights about the widely used remediation techniques (chemical reduction and advanced oxidation) used separately or combined.

\section{Acknowledgements}

The authors gratefully acknowledge the financial support of this work by ADEME “Agence de l'Environnement et de la Maîtrise de l'Energie” and Region Bretagne. 


\section{References}

Agency for Toxic Substances and Disease Registry (ATSDR) (2000) Toxicological profile for polychlorinated biphenyls (PCBs).

Al-Shamsi MA and Thomson NR (2013) Treatment of organic compounds by activated persulfate using nanoscale zerovalent iron. Ind Eng Chem Res 52: 13564-13571

Andy Hong PK, Nakra S, Jimmy Kao CM, Hayes DF (2004) Pressure-assisted ozonation of PCB and PAH contaminated sediments. Chemosphere 72 (11): 1757-1764.

Anitescu G, Tavlaride LL (2005) Oxidation of biphenyl in supercritical water: reaction kinetics, key pathways, and main products. Ind Eng Chem Res 44: 1226-1232.

Aristov N, Habekost A (2010) Heterogeneous dehalogenation of PCBs with iron/toluene or iron/quicklime. Chemosphere 80: 113-115.

Bogan BW, Trbovic V (2003) Effect of sequestration on PAH degradability with Fenton's reagent: roles of total organic carbon, humin, and soil porosity. J Hazard Mater 100: $285-300$

Cavanagh. J.-A.E. (2006) Comparison of soil guideline values used in New Zealand and their derivations. Landcare Research Contract Report. LC0607/025.

CCME (Canadian Council of Ministers of Environment) (1999) Canadian soil quality guidelines for the protection of environmental and human health. Total PCBs.

Choi H, Al-Abed SR, Agarwal S, Dionysiou DD (2008) Synthesis of reactive nano-Fe/Pd bimetallic system-impregnated activated carbon for the simultaneous adsorption and dechlorination of PCBs. Chem Mater 20: 3649-3655.

Christensen A, Gurol MD, Garoma T (2009) Treatment of persistent organic compounds by integrated advanced oxidation processes and sequential batch reactor. Water Res 43: $3910-3921$. 
Chuang F-W, Larson RA, Scully Wessman M (1995) Zero-valent iron-promoted dechlorination of polychlorinated biphenyls. Environ Sci Technol 29: 2460-2463.

Cushing BL, Kolesnichenko VL, O'Connor CJ (2004) Recent advances in the liquid-phase syntheses of inorganic nanoparticles. Chem. Rev 104: 3893-3946.

David I, Welch AJE (1956) The oxidation of magnetite and related spinels. Constitution of gamma ferric oxide. T Faraday Soc 52: 1642-1650.

EPA (Environmental Protection Authority) Victoria (2009) Environment protection (Industrial Waste Resource) regulations 2009. S.R. No. 77/2009.

Fan G, Fan G, Cang L, Gomes HI, Zhou D (2016) Electrokinetic delivery of persulfate to remediate PCBs polluted soils: Effect of different activation methods. Chemosphere 144: 138-147.

Fang Y, Al-Abed SR (2008) Correlation of 2-chlorobiphenyl dechlorination by Fe/Pd with iron corrosion at different pH. Environ Sci Technol 42: 6942-6948.

Fang G-D, Dionysiou DD, Zhou D-M, Wang Y, Zhu X-D, Fan J-X, Cang L, Wang Y-J (2013a) Transformation of polychlorinated biphenyls by persulfate at ambient temperature. Chemosphere 90: 1573-1580.

Fang G, Gao J, Dionysiou DD, Liu C, Zhou D (2013b) Activation of persulfate by quinones: free radical reactions and implication for the degradation of PCBs. Environ Sci Technol 47: 4605-4611.

Feng J, Lim TT (2005) Pathways and kinetics of carbon tetrachloride and chloroform reductions by nanoscale $\mathrm{Fe}$ and Fe/Ni particles: comparison with commercial microscale Fe and Zn. Chemosphere 58: 1267-1277.

Flotron V, Delteil C, Padellec Y, Camel V (2005) Removal of sorbed polycyclic aromatic hydrocarbons from soil, sludge and sediment samples using the Fenton's reagent process. Chemosphere 59: 1427-1437. 
Girvin DC, Scott AJ (1997) Polychlorinated biphenyl sorption by soils: Measurement of soil-water partition coefficients at equilibrium. Chemosphere 35: 2007-2025.

Goi A, Trapido M (2004) Degradation of polycyclic aromatic hydrocarbons in soil: The Fenton reagent versus ozonation. Environ Technol 25: 155-164.

Gomes HI, Dias-Ferreira C, Ribeiro AB (2013) Overview of in situ and ex situ remediation technologies for PCB-contaminated soils and sediments and obstacles for full-scale application. Sci Total Environ 445-446: 237-260.

Gomes HI, Dias-Ferreira C, Ottosen LM, Ribeiro AB (2014) Electrodialytic remediation of polychlorinated biphenyls contaminated soil with iron nanoparticles and two different surfactants. J Colloid Interf Sci 433: 189-195.

Gomes HI, Dias-Ferreira C, Ottosen LM, Ribeira AB (2015) Electroremediation of PCB contaminated soil combined with iron nanoparticles: effect of soil type. Chemosphere 131: 157-163.

Grittini C, Malcomson M, Fernando Q, Korte N (1995) Rapid dechlorination of polychlorinated biphenyls on the surface of a Pd/Fe bimetallic system. Environ Sci Technol 29: 2898-2900.

He F, Zhao D (2005) Preparation and characterization of a new class of starch-stabilized bimetallic nanoparticles for degradation of chlorinated hydrocarbons in water. Environ Sci Technol 39: 3314-3320.

He N, Li P, Zhou Y, Ren W, Fan S, Verkhozina VA (2009) Catalytic dechlorination of polychlorinated biphenyls in soil by palladium-iron bimetallic catalyst. J Hazard Mater 164: 126-132.

Hornbuckle K, Robertson L (2010) Polychlorinated biphenyls (PCBs): sources, exposures, toxicities. Environ Sci Technol 44: 2749-2751. 
Hong Y, Rheem Y, Lai MY, Cwiertny DM, Walker SL, Myung NV (2009) Electrochemical synthesis of $\mathrm{Fe}_{\mathrm{x}} \mathrm{Ni}_{1-\mathrm{x}}$ nanostructures for environmental remediation. Chem Eng J, 151 66-72.

Javorská H, Tlustoš P, Komárek M, Leštan D, Kaliszová R, Száková J (2008) Evaluation of chemical treatments for a mixed contaminant soil. J Environ Eng 134 (9): 743-749.

Jonsson S, Persson Y, Frankki S, van Bavel B, Lundstedt S, Haglund P, Tysklind M (2007) Degradation of polycyclic aromatic hydrocarbons (PAHs) in contaminated soils by Fenton's reagent: A multivariate evaluation of the importance of soil characteristics and PAH properties. J Hazard Mater 149: 86-96.

Kanel SR, Greneche J-M, Choi HS (2006) Arsenic (V) Removal from groundwater using nano scale zero-valent iron as a colloidal reactive barrier material. Environ Sci Technol 40: 2045-2050.

Kaštánek F, Demnerová K, Pazlarová J, Burkhard J, Maléterová Y (1999) Biodegradation of polychlorinated biphenyls and volatile chlorinated hydrocarbons in contaminated soils and ground water in field condition. Int Biodeter Biodegr 44: 39-47.

Katsoyiannis IA, Ruettimann T, Hug SJ (2008) pH dependence of fenton reagent generation and As(III) oxidation and removal by corrosion of zero valent iron in aerated water. Environ Sci Technol 42: 7424-7430

Kawahara FK, Davila B, Al-Abed SR, Vesper SJ, Ireland JC, Rock S (1995) Polynuclear aromatic hydrocarbon $(\mathrm{PAH})$ release from soil during treatment with Fenton's Reagent. Chemosphere 31: 4131-4142.

Keenan CR, Sedlak DL (2008) Factors affecting the yield of oxidants from the reaction of nanonarticulate zero-valent iron and oxygen. Environ Sci Technol 42: 1262-1267 
Koenig S, Fernandez P, Sole M (2012) Differences in cytochrome P450 enzyme activities between fish and crustacea: relationship with the bioaccumulation patterns of polychlorobiphenyls (PCBs). Aquat Toxicol 108: 11-17.

Korte NE, West OR, Liang L, Gu B, Zutman JL, Fernando Q (2002) The effect of solvent concentration on the use of palladized-iron for the step-wise dechlorination of polychlorinated biphenyls in soil extracts. Waste Manage 22: 343-349.

Kubatova A, Herman J, Steckler TS, de Veij M, Miller DJ, Klunder EB, Wai CM, Hawthore SB (2003) Subcritical (Hot/Liquid) Water Dechlorination of PCBs (Aroclor 1254) with Metal Additives and in Waste Paint. Environ Sci Technol 37: 5757-5762.

Lauby-Secretan B, Loomis D, Grosse Y, Ghissassi F El, Bouvard V, Benbrahim-Tallaa L, Guha N, R. Baan, Mattock H, Straif K (2013) Carcinogenicity of polychlorinated biphenyls and polybrominated biphenyls. Lancet Oncol 14: 287-288.

Li XQ, Zhang WX (2006) Iron Nanoparticles: the Core-shell structure and unique properties for $\mathrm{Ni}(\mathrm{II})$ sequestration. Langmuir (22): 4638-4642.

Liang C, Lai MC (2008) Trichloroethylene degradation by zero valent iron activated persulfate oxidation. Environ Eng Sci 25 (7): 1071-1077.

Lindsey ME, Xu G, Lu J, Tarr MA (2003) Enhanced Fenton degradation of hydrophobic organics by simultaneous iron and pollutant complexation with cyclodextrins. Sci Total Environ 307: 215-229.

Lowry GV, Johnson KM (2004) Congener-specific dechlorination of dissolved PCBs by microscale and nanoscale zerovalent iron in a water/methanol solution. Environ Sci Technol 38: 5208-5216

Luo H, Jin S, Fallgren PH, Colberg PJS, Johnson PA (2010) Prevention of iron passivation and enhancement of nitrate reduction by electron supplementation. Chem Eng J (160): 185-189. 
Maloney Ph, DeVor R, Novaes-Card S, Saitta E, Quinn J, Clausen CA, Geiger CL (2011) Dechlorination of polychlorinated byphenyls using magnesium and acidified alcohols. J Hazard Mater 187: 235-240.

Meijer SN, Ockenden WA, Sweetman A, Breivik K, Grimalt JO, Jones KC (2003) Global distribution and budget of PCBs and HCB in background surface soils: implications for sources and environmental processes. Environ Sci Technol 37: 667-672.

Ponder SM, Darab JG, Mallouk TE (2000) Remediation of $\mathrm{Cr}(\mathrm{VI})$ and $\mathrm{Pb}(\mathrm{II})$ aqueous solutions using supported, nanoscale zero-valent iron. Environ Sci Technol 34: 2564 2569.

Porta M, Zumeta E (2002) Implementing the Stockholm treaty on persistent organic pollutants. Occup Environ Med 10: 651-652.

Quiroga JM, Riaza A, Manzano MA (2009) Chemical degradation of PCB in the contaminated soils slurry: direct Fenton oxidation and desorption combined with the photo-Fenton process. J Environ Sci and Heal A 44: 1120-1126.

Ramos MAV, Yan W, Li X, Koel BE, Zhang W (2009) Simultaneous oxidation and reduction of arsenic by zero-valent iron nanoparticles: understanding the significance of the core-shell structure. J Phys Chem C, 113: 14591-14594.

Rastogi A, Al-Abed SR, Dionysiou DD (2009) Sulfate radical-based ferrousperoxymonosulfate oxidative system for PCBs degradation in aqueous and sediment systems. Appl Catal B-Environ, 85: 171-179.

Romero A, Santos A, Cordero T, Rodríguez-Mirasol J, Rosas JM, Vicente F (2011) Soil remediation by Fenton-like process: phenol removal and soil organic matter modification. Chem Eng J 170: 36-43. 
Salazar-Camacho C, Villalobos M, de la Luz Rivas-Sánchez M, Arenas-Alatorre J, AlcarazCienfuegos J, Gutiérrez-Ruiz ME (2013) Characterization and surface reactivity of natural and synthetic magnetites. Chem Geol 347: 233-247.

Schrick B, Blough JL, Jones AD, Mallouk TE (2012) Hydrodechlorination of trichloroethylene to hydrocarbons using bimetallic nickel-iron nanoparticles. Chem Mater 14: 5140-5147.

Schwertmann U, Cornell RM (2000) Iron oxides in the laboratory: preparation and characterization. Wiley-VCH, New York

Sedlak DL, Andren AW (1991) Aqueous-phase oxidation of polychlorinated biphenyls by hydroxyl radicals. Environ Sci Technol 25: 1419-1426.

Sidhu PS, Gilkes RJ, Posner AM (1978) The synthesis and some properties of Co, Ni, Zn, $\mathrm{Cu}, \mathrm{Mn}$ and Cd substituted magnetites. J Inorg Nucl Chem 40: 429-435.

Sun Y, Takaoka M, Takeda N, Matsumoto T, Oshita. K (2006a) Kinetics on the decomposition of polychlorinated biphenyls with activated carbon-supported iron. Chemosphere. 65: 183-189.

Sun Y-P, Li X, Cao J, Zhang W, Wang HP (2006b) Characterization of zero-valent iron nanoparticles. Advances in Colloid and Interface Sci 120: 47-56.

Sung HJ, Feitz AJ, Sedlak DL, Waite TD (2005) Quantification of the oxidizing capacity of nanoparticulate zero-valent iron. Environ Sci Technol 39: 1263-1268.

Tang X, Hashmi MZ, Zeng B, Yang J, Shen Ch (2015) Application of iron-activated persulfate oxidation for the degradation of PCBs in soil. Chem Eng J 279: 673-680.

USEPA (United States Environmental Protection Agency) (2012) PCB Regulations at 40 CFR Part 761. Toxic Substances Control Act. 
Usman M, Faure P, Hanna K, Abdelmoula M, Ruby C (2012a) Application of magnetite catalyzed chemical oxidation (Fenton-like and persulfate) for the remediation of oil hydrocarbon contamination. Fuel 96: 270-276.

Usman M, Faure P, Ruby C, Hanna K (2012b) Remediation of PAH-contaminated soils by magnetite catalyzed Fenton-like oxidation. Appl Catal B-Environ 117-118: 10-17

Usman M, Faure P, Ruby C, Hanna K (2012c) Application of magnetite-activated persulfate oxidation for the degradation of PAHs in contaminated soils. Chemosphere 87: 234240.

Varanasi P, Fullana Y, Sidhu S (2006) Remediation of PCB contaminated soils using iron nanoparticles. Chemosphere 66: 1031-1038.

Venkatachalam K, Arzuaga X, Chopra N, Gavalas VG, Xu J, Bhattacharyya D, Hennig B, Bachas LG (2008) Reductive dechlorination of 3,3',4,4'-tetrachlorobiphenyl (PCB77) using palladium or palladium/iron nanoparticles and assessment of the reduction in toxic potency in vascular endothelial cells. J Hazard Mater 159: 483-491.

Viglianti C, Hanna K, de Brauera C, Germain P (2006) Removal of polycyclic aromatic hydrocarbons from aged-contaminated soil using cyclodextrins: Experimental study. Environ. Poll 140: 427-435.

Waisner S, Medina VF, Morrow AB, Nestler CC (2008) Pressure-assisted ozonation of PCB and PAH contaminated sediments. Chemosphere 72 (11): 1757-1764.

Wang C-B, Zhang W-X (1997) Synthesizing nanoscale iron particles for rapid and complete dechlorination of TCE and PCBs. Environ Sci Technol 31: 2154-2156.

Wu JJ, Muruganandham M, Yang JS, Lin SS (2006) Oxidation of DMSO on goethite catalyst in the presence of $\mathrm{H}_{2} \mathrm{O}_{2}$ at neutral pH. Catal Commun 7: 901-906. 
$\mathrm{Xu} \mathrm{J}$, Bhattacharyya D (2007) Fe/Pd nanoparticle immobilization in microfiltration membrane pores: synthesis, characterization, and application in the dechlorination of polychlorinated biphenyls. Ind Eng Chem Res 46: 2348-2359.

Xue X, Hanna K, Abdelmoula M, Deng N (2009) Adsorption and oxidation of PCP on the surface of magnetite: kinetic experiments and spectroscopic investigations. Appl Catal B-Environ, 89: 432-440.

Yak HK, Wenclawiak BW, Cheng IF, Doyle JG, Wai CM (1999) Reductive dechlorination of polychlorinated biphenyls by zerovalent iron in subcritical water. Environ Sci Technol 33: 1307-1310.

Yang B, Deng S, Yu G, Zhang H, Wu J, Zhuo Q (2011) Bimetallic Pd/Al particles for highly efficient hydrodechlorination of 2-chlorobiphenyl in acidic aqueous solution. J Hazard Mater 189: 76-83.

Yu W, Zhang T, Zhang J, Qiao X, Yang L, Liu Y (2006) The synthesis of octahedral nanoparticles of magnetite. Mater Lett 60: 2998-3001.

Zha S, Cheng Y, Gao Y, Chen Z, Megharaj M, Naidu R (2014) Nanoscale zero-valent iron as a catalyst for heterogeneous Fenton oxidation of amoxicillin. Chem Eng J 255: $141-148$

Zhang L, Manthiram A (1997) Chains composed of nanosize metal particles and identifying the factors driving their formation. Applied Physics Letters, 70: 2469.

Zhang Z, Hu S, Baig SA, Tang J, Xu X (2012) Catalytic dechlorination of Aroclor 1242 by Fe-Ni bimetallic nanoparticles. J Colloid Interf Sci 385: 160-165.

Zhu N, Li Y, Zhang F (2011) Catalytic dechlorination of polychlorinated biphenyls in subcritical water by Ni/Fe nanoparticles. Chem Eng J 171: 919-925.

Zhuang Y, Ahn S, Seyfferth AL, Masue-Slowey Y, Fendorf S, Luthy RG (2011) Dehalogenation of polybrominated diphenyl ethers and polychlorinated biphenyl by 
bimetallic, impregnated, and nanoscale zerovalent iron. Environ Sci Technol 45: 4896-4903. 


\section{Tables captions}

Table 1. Physical and chemical characteristics of the investigated soil.

Table 2. The residuals of different PCBs in contaminated soil $(\leq 500 \mu \mathrm{m})$ and in its further separated fractions (F1: $\leq 250 \mu \mathrm{m}$ and $\mathrm{F} 2: 250-500 \mu \mathrm{m})$.

Table 3. Summary of experimental conditions.

Table 4. Diameters and BET surface areas of synthesized nanoparticles.

Table 5. Elemental composition of nanoparticles by EDS.

Table 6. Apparent surface composition of nanoparticles by XPS. 
Table 1. Physical and chemical characteristics of the investigated soil.

\begin{tabular}{|c|c|c|}
\hline Parameter & Value & Unit \\
\hline \multicolumn{3}{|l|}{ Soil texture } \\
\hline Silt & 49.2 & $\%$ \\
\hline Clay & 16.0 & $\%$ \\
\hline Sand & 34.8 & $\%$ \\
\hline $\mathrm{pH}$ (in water) & 7.9 & - \\
\hline Humidity & 1.5 & $\%$ \\
\hline Cation exchange capacity & 10.3 & meq $/ 100$ \\
\hline Calcium carbonate $\left(\mathrm{CaCO}_{3}\right)$ & 33.1 & $\%$ \\
\hline Total nitrogen $(\mathrm{N})$ & 1.8 & $\mathrm{~g} \mathrm{~kg}^{-1}$ \\
\hline Soil organic matter (SOM) & 3.9 & $\%$ \\
\hline \multicolumn{3}{|l|}{ Exchangeable cations } \\
\hline Calcium exchangeable $(\mathrm{CaO})$ & 10580 & $\mathrm{mg} \mathrm{kg}^{-1}$ \\
\hline Magnesium exchangeable (MgO) & 526 & $\mathrm{mg} \mathrm{kg}^{-1}$ \\
\hline Potassium exchangeable $\left(\mathrm{K}_{2} \mathrm{O}\right)$ & 2373 & $\mathrm{mg} \mathrm{kg}^{-1}$ \\
\hline Phosphor assimilable $\left(\mathrm{P}_{2} \mathrm{O}_{5}\right)$ & 380 & $\mathrm{mg} \mathrm{kg}^{-1}$ \\
\hline Sodium exchangeable $\left(\mathrm{Na}_{2} \mathrm{O}\right)$ & 1798 & $\mathrm{mg} \mathrm{kg}^{-1}$ \\
\hline \multicolumn{3}{|l|}{ Metals } \\
\hline Cadmium $(\mathrm{Cd})$ & 6.65 & $\mathrm{mg} \mathrm{kg}^{-1}$ \\
\hline Chromium $(\mathrm{Cr})$ & 586 & $\mathrm{mg} \mathrm{kg}^{-1}$ \\
\hline Total copper $(\mathrm{Cu})$ & 272 & $\mathrm{mg} \mathrm{kg}^{-1}$ \\
\hline Nickel (Ni) & 464 & $\mathrm{mg} \mathrm{kg}^{-1}$ \\
\hline Lead $(\mathrm{Pb})$ & 580 & $\mathrm{mg} \mathrm{kg}^{-1}$ \\
\hline Total Zinc (Zn) & 1070 & $\mathrm{mg} \mathrm{kg}^{-1}$ \\
\hline Mercury (Hg) & 1.74 & $\mathrm{mg} \mathrm{kg}^{-1}$ \\
\hline Total Iron (Fe) & 13124 & $\mathrm{mg} \mathrm{kg}^{-1}$ \\
\hline Total Manganese (Mn) & 852 & $\mathrm{mg} \mathrm{kg}^{-1}$ \\
\hline Aluminium (Al) & 25200 & $\mathrm{mg} \mathrm{kg}^{-1}$ \\
\hline Arsenic (As) & 41.9 & $\mathrm{mg} \mathrm{kg}^{-1}$ \\
\hline
\end{tabular}


Table 2. The residuals of different PCBs in contaminated soil $(\leq 500 \mu \mathrm{m})$ and in its further separated fractions (F1: $\leq 250 \mu \mathrm{m}$ and $\mathrm{F} 2: 250-500 \mu \mathrm{m})$.

\begin{tabular}{|c|c|c|c|c|}
\hline \multirow[t]{2}{*}{$P C B$} & \multirow[t]{2}{*}{ Congener } & \multicolumn{3}{|c|}{ Concentration, $\mathrm{mg} \mathrm{kg}^{-1}$} \\
\hline & & Fraction $\leq 500 \mu m$ & Fraction $F 1 \leq 250 \mu m$ & Fraction F2 250-500 $\mu \mathrm{m}$ \\
\hline PCB 18 & tri-CB & $<\mathrm{LQ}$ & $0.2 \pm 0$ & $<\mathrm{LQ}$ \\
\hline PCB 28 & tri-CB & $<\mathrm{LQ}$ & $<\mathrm{LQ}$ & $<\mathrm{LQ}$ \\
\hline PCB 31 & tri-CB & $<\mathrm{LQ}$ & $<\mathrm{LQ}$ & $<\mathrm{LQ}$ \\
\hline PCB 44 & tetra-CB & $3.2 \pm 0.2$ & $3.7 \pm 0.2$ & $1.8 \pm 0.1$ \\
\hline PCB 52 & tetra-CB & $10.0 \pm 0.7$ & $12.3 \pm 1.0$ & $5.7 \pm 0.5$ \\
\hline PCB 77 & tetra-CB & $<\mathrm{LQ}$ & $<\mathrm{LQ}$ & $<\mathrm{LQ}$ \\
\hline PCB 101 & penta-CB & $33.9 \pm 3.8$ & $43.8 \pm 2.3$ & $17.9 \pm 1.9$ \\
\hline PCB 110 & penta-CB & $27.2 \pm 1.6$ & $34.9 \pm 0.8$ & $14.6 \pm 0.5$ \\
\hline PCB 118 & penta-CB & $23.6 \pm 1.1$ & $32.0 \pm 0.7$ & $11.7 \pm 0.4$ \\
\hline PCB 138 & hexa-CB & $74.2 \pm 3.6$ & $89.6 \pm 6.5$ & $41.8 \pm 1.0$ \\
\hline PCB 149 & hexa-CB & $51.2 \pm 3.2$ & $65.0 \pm 1.5$ & $28.7 \pm 1.0$ \\
\hline PCB 153 & hexa-CB & $80.8 \pm 6.3$ & $106.5 \pm 3.1$ & $46.7 \pm 2.41$ \\
\hline PCB 156 & hexa-CB & $7.4 \pm 0.3$ & $9.9 \pm 0.9$ & $3.5 \pm 0.2$ \\
\hline PCB 167 & hexa-CB & $8.6 \pm 1.1$ & $6.7 \pm 0.2$ & $4.8 \pm 0.4$ \\
\hline PCB 170 & hepta-CB & $42.0 \pm 2.0$ & $56.5 \pm 3.1$ & $41.2 \pm 1.3$ \\
\hline PCB 180 & hepta-CB & $76.5 \pm 3.3$ & $90.9 \pm 4.7$ & $21.6 \pm 0.7$ \\
\hline PCB 194 & octa-CB & $11.6 \pm 0.5$ & $16.9 \pm 0.1$ & $5.8 \pm 0.3$ \\
\hline PCB total & & $450.2 \pm 31.8$ & $568.7 \pm 25.2$ & $245.8 \pm 10.8$ \\
\hline
\end{tabular}


Table 3. Summary of experimental conditions.

\begin{tabular}{|c|c|c|c|c|c|}
\hline $\begin{array}{c}\text { Soil } \\
\text { (Solid/liquid, S/L) }\end{array}$ & Experiment & Particle & $\begin{array}{l}\text { Particle loading } \\
\quad\left(\mathrm{g} \mathrm{g}^{-1} \text { of soil }\right)\end{array}$ & Oxidant dose & Duration (h) \\
\hline \multirow[t]{6}{*}{$\begin{array}{c}\text { Spiked sand } \\
(S / L=1: 1)\end{array}$} & \multirow[t]{2}{*}{ Reduction } & $\mathrm{Fe}^{0}$ or $\mathrm{Fe} / \mathrm{Ni}$ & $\begin{array}{c}0.25 \\
0.125,0.5 \\
\end{array}$ & - & $\begin{array}{c}24,48,240 \\
48\end{array}$ \\
\hline & & $\mathrm{Fe}_{3} \mathrm{O}_{4}$ or $\mathrm{Fe}_{3 \mathrm{x}} \mathrm{Ni}_{\mathrm{x}} \mathrm{O}_{4}$ & 0.25 & - & 24,48 \\
\hline & Oxidation $\left(\mathrm{H}_{2} \mathrm{O}_{2}\right)$ & $\mathrm{Fe}^{0}$ or $\mathrm{Fe}_{3} \mathrm{O}_{4}$ & 0.25 & $2 \mathrm{M}$ & 24,48 \\
\hline & Oxidation $\left(\mathrm{K}_{2} \mathrm{~S}_{2} \mathrm{O}_{8}\right)$ & $\mathrm{Fe}^{0}$ or $\mathrm{Fe}_{3} \mathrm{O}_{4}$ & 0.25 & $180 \mathrm{mM}$ & 24,48 \\
\hline & Reduction + Oxidation $\left(\mathrm{H}_{2} \mathrm{O}_{2}\right)$ & $\mathrm{Fe}^{0}$ or $\mathrm{Fe}_{3} \mathrm{O}_{4}$ & 0.25 & $2 \mathrm{M}$ & $24+48$ \\
\hline & Reduction + Oxidation $\left(\mathrm{K}_{2} \mathrm{~S}_{2} \mathrm{O}_{8}\right)$ & $\mathrm{Fe}^{0}$ or $\mathrm{Fe}_{3} \mathrm{O}_{4}$ & 0.25 & $180 \mathrm{mM}$ & $24+48$ \\
\hline \multirow{11}{*}{$\begin{array}{c}\text { Soil (fraction } F \\
<500 \mu m) \\
(S / L=1: 1)\end{array}$} & Reduction & $\mathrm{Fe}^{0}, \mathrm{Fe} / \mathrm{Ni}, \mathrm{Fe}_{3} \mathrm{O}_{4}$ or $\mathrm{Fe}_{3 \mathrm{x}} \mathrm{Ni}_{\mathrm{x}} \mathrm{O}_{4}$ & $\begin{array}{c}0.25 \\
0.5 \\
\end{array}$ & - & $\begin{array}{c}24,48,240 \\
48 \\
\end{array}$ \\
\hline & with Ethanol & $\mathrm{Fe} / \mathrm{Ni}$ & 0.25 & - & 48 \\
\hline & with Cyclodextrin & $\mathrm{Fe} / \mathrm{Ni}$ & 0.25 & - & 48 \\
\hline & at $\mathrm{pH} 4$ & $\mathrm{Fe} / \mathrm{Ni}$ & 0.25 & - & 48 \\
\hline & \multirow{3}{*}{ Oxidation $\left(\mathrm{H}_{2} \mathrm{O}_{2}\right)$} & $\mathrm{Fe}^{0}, \mathrm{Fe} / \mathrm{Ni}, \mathrm{Fe}_{3} \mathrm{O}_{4}$ or $\mathrm{Fe}_{3 \mathrm{x}} \mathrm{Ni}_{\mathrm{x}} \mathrm{O}_{4}$ & 0.25 & $2 \mathrm{M}$ & 24,48 \\
\hline & & $\mathrm{Fe}_{3} \mathrm{O}_{4}$ & 0.25 & $0.2,1,2 \mathrm{M}$ & 48 \\
\hline & & $\mathrm{Fe}_{3} \mathrm{O}_{4}$ & 0.25 & $0.2 \mathrm{M}(\mathrm{x} 1, \mathrm{x} 5, \mathrm{x} 10)$ & $24,120,240$ \\
\hline & \multirow{2}{*}{ Oxidation $\left(\mathrm{K}_{2} \mathrm{~S}_{2} \mathrm{O}_{8}\right)$} & $\mathrm{Fe}^{0}, \mathrm{Fe} / \mathrm{Ni}, \mathrm{Fe}_{3} \mathrm{O}_{4}$ or $\mathrm{Fe}_{3 \mathrm{x}} \mathrm{Ni}_{\mathrm{x}} \mathrm{O}_{4}$ & 0.25 & $180 \mathrm{mM}$ & 24,48 \\
\hline & & $\mathrm{Fe}_{3} \mathrm{O}_{4}$ & 0.25 & $45,90,180 \mathrm{mM}$ & 48 \\
\hline & Reduction + Oxidation $\left(\mathrm{H}_{2} \mathrm{O}_{2}\right)$ & $\mathrm{Fe}^{0}, \mathrm{Fe} / \mathrm{Ni}, \mathrm{Fe}_{3} \mathrm{O}_{4}$ or $\mathrm{Fe}_{3 \mathrm{x}} \mathrm{Ni}_{\mathrm{x}} \mathrm{O}_{4}$ & 0.25 & $2 \mathrm{M}$ & $24+48$ \\
\hline & Reduction + Oxidation $\left(\mathrm{K}_{2} \mathrm{~S}_{2} \mathrm{O}_{8}\right)$ & $\mathrm{Fe}^{0}, \mathrm{Fe} / \mathrm{Ni}, \mathrm{Fe}_{3} \mathrm{O}_{4}$ or $\mathrm{Fe}_{3 \mathrm{x}} \mathrm{Ni}_{\mathrm{x}} \mathrm{O}_{4}$ & 0.25 & $180 \mathrm{mM}$ & $24+48$ \\
\hline $\begin{array}{c}\text { Sand spiked } \\
\text { with EOM } \\
(S / L=1: 1) \\
\end{array}$ & Oxidation $\left(\mathrm{H}_{2} \mathrm{O}_{2}\right)$ & $\mathrm{Fe}_{3} \mathrm{O}_{4}$ & 0.25 & $0.2 \mathrm{M}(\mathrm{x} 1, \mathrm{x} 5, \mathrm{x} 10)$ & $24,120,240$ \\
\hline $\begin{array}{c}\text { Soil (fractions } F 1 \\
<250 \mu m \text { and } F 2 \\
250-500 \mu m) \\
(S / L=1: 1)\end{array}$ & Reduction & $\mathrm{Fe}^{0}$ or $\mathrm{Fe} / \mathrm{Ni}$ & 0.25 & - & 48 \\
\hline
\end{tabular}


Table 4. Diameters and BET surface areas of synthesized nanoparticles.

\begin{tabular}{lcc}
\hline \multicolumn{1}{c}{ Analyzed nanoparticles } & $\begin{array}{c}\text { Diameter, according } \\
\text { to TEM images }(\mathrm{nm})\end{array}$ & $\begin{array}{c}\text { BET surface } \\
\text { area }\left(\mathrm{m}^{2} \mathrm{~g}^{-1}\right)\end{array}$ \\
\hline Iron $\left(\mathrm{Fe}^{0}\right)$ & $20-50$ & 40.2 \\
\hline Bimetallic nanoparticles $(\mathrm{Fe} / \mathrm{Ni})$ & $10-20$ & 75.4 \\
\hline Magnetite $\left(\mathrm{Fe}_{3} \mathrm{O}_{4}\right)$ & $<20$ & 59.8 \\
\hline Ni-substituted magnetite $\left(\mathrm{Fe}_{3-\mathrm{x}} \mathrm{Ni}_{\mathrm{x}} \mathrm{O}_{4}\right)$ & $20-100$ & 48.3 \\
\hline
\end{tabular}

Table 5.

\begin{tabular}{lcccccc}
\hline \multicolumn{1}{c}{ Analyzed nanoparticles } & $\% \mathrm{Fe}$ & $\% \mathrm{Ni}$ & $\% \mathrm{O}$ & $\% \mathrm{C}$ & $\% \mathrm{Na}$ & $\% \mathrm{~K}$ \\
\hline Iron $\left(\mathrm{Fe}^{0}\right)$ & 66.70 & - & 20.10 & 2.6 & 8.13 & - \\
\hline Bimetallic nanoparticles $(\mathrm{Fe} / \mathrm{Ni})$ & 50.77 & 18.66 & 15.13 & 14.32 & 1.11 & - \\
\hline Magnetite $\left(\mathrm{Fe}_{3} \mathrm{O}_{4}\right)$ & 64.93 & - & 28.86 & 6.21 & - & - \\
\hline Substituted magnetite $\left(\mathrm{Fe}_{3 \mathrm{x}} \mathrm{Ni}_{\mathrm{x}} \mathrm{O}_{4}\right)$ & 56.58 & 2.32 & 30.56 & 9.93 & - & 0.62 \\
\hline
\end{tabular}

Table 6.

\begin{tabular}{lccccccccc}
\hline \multicolumn{1}{c}{ Analyzed nanoparticles } & $\% \mathrm{Fe}$ & $\% \mathrm{Ni}$ & $\% \mathrm{O}$ & $\% \mathrm{C}$ & $\% \mathrm{Na}$ & $\% \mathrm{~B}$ & $\% \mathrm{~S}$ & $\% \mathrm{Cl}$ & $\% \mathrm{~K}$ \\
\hline Iron $\left(\mathrm{Fe}^{0}\right)$ & 41.0 & - & 40.18 & 1.93 & 9.48 & 5.27 & 2.14 & - & - \\
\hline Bimetallic nanoparticles $(\mathrm{Fe} / \mathrm{Ni})$ & 14.55 & 2.48 & 42.21 & 2.9 & 25.33 & 6.6 & 5.93 & - & - \\
\hline Magnetite $\left(\mathrm{Fe}_{3} \mathrm{O}_{4}\right)$ & 68.29 & - & 28.72 & 2.18 & - & - & 0.60 & 0.22 & - \\
\hline Substituted magnetite $\left(\mathrm{Fe}_{3 \times} \mathrm{Ni}_{\mathrm{x}} \mathrm{O}_{4}\right)$ & 52.9 & 1.65 & 34.42 & 10.32 & - & - & 0.39 & - & 0.28 \\
\hline
\end{tabular}




\section{Figure captions}

Figure 1. Transmission electron microscopy images of $\mathrm{Fe}^{0}$, $\mathrm{Fe} / \mathrm{Ni}, \mathrm{Fe}_{3} \mathrm{O}_{4}$ and $\mathrm{Fe}_{3 x} \mathrm{Ni}_{\mathrm{x}} \mathrm{O}_{4}$.

Figure 2. (A) Reductive transformation of PCB28 and PCB118 in spiked sand in presence of different iron nanoparticles: $[\mathrm{PCB}]_{0}=5 \mu \mathrm{g} \mathrm{g}^{-1},\left[\mathrm{Fe}^{0}, \mathrm{Fe} / \mathrm{Ni}, \mathrm{Fe}_{3} \mathrm{O}_{4}\right.$ or $\left.\mathrm{Fe}_{3-\mathrm{x}} \mathrm{Ni}_{\mathrm{x}} \mathrm{O}_{4}\right]=0.25 \mathrm{~g} \mathrm{~g}^{-1}$ of sand, $\mathrm{L} / \mathrm{S}=1: 1$, $\mathrm{pH}=7.2 \pm 0.3, \mathrm{~T}=20 \pm 2{ }^{\circ} \mathrm{C}$. (B) Effect of nanoparticles dosage on efficiency of reductive transformation: $\mathrm{L} / \mathrm{S}=1: 1, \mathrm{pH}=7.2 \pm 0.3$, reaction time: $48 \mathrm{~h}$.

Figure 3. Degradation of PCB28 and PCB118 in spiked sand in presence of $\mathrm{Fe}^{0}$ and $\mathrm{Fe}_{3} \mathrm{O}_{4}$ nanoparticles and oxidants; $(\mathbf{A}, \mathbf{B})$ direct oxidation and $(\mathbf{B})$ combined approach (oxidant added at $\mathrm{t}=24 \mathrm{~h}):[\mathrm{PCB}]_{0}=5 \mu \mathrm{g} \mathrm{g}^{-1},\left[\mathrm{Fe}^{0}\right]$ or $[\mathrm{Fe} / \mathrm{Ni}]=0.25 \mathrm{~g} \mathrm{~g}^{-1}$ of sand, $\mathrm{L} / \mathrm{S}=1: 1,\left[\mathrm{H}_{2} \mathrm{O}_{2}\right]=2 \mathrm{M} ;\left[\mathrm{K}_{2} \mathrm{~S}_{2} \mathrm{O}_{8}\right]=$ $180 \mathrm{mM}, \mathrm{pH}=7.2 \pm 0.3, \mathrm{~T}=20 \pm 2{ }^{\circ} \mathrm{C}$.

Figure 4. (A, B) Degradation of PCBs in historically contaminated soil in presence of different nanoparticles: $\left[\mathrm{Fe}^{0}\right]$ or $[\mathrm{Fe} / \mathrm{Ni}]=0.25 \mathrm{~g} \mathrm{~g}^{-1}$ of soil, $\mathrm{L} / \mathrm{S}=1: 1, \mathrm{pH}=8.2 \pm 0.3, \mathrm{~T}=20 \pm 2{ }^{\circ} \mathrm{C}$.

(C) Effect of nanoparticles dosage on efficiency of reductive transformation: $\mathrm{L} / \mathrm{S}=1: 1, \mathrm{pH}=8.2 \pm 0.3$, reaction time: $48 \mathrm{~h}$.

Figure 5. Comparison of degradation efficiency of different nanoparticles in $(\mathbf{A}, \mathbf{B})$ direct oxidation and $(\mathbf{C})$ combined approach (oxidant added at $\mathrm{t}=24 \mathrm{~h}$ ): $\left[\mathrm{Fe}^{0}, \mathrm{Fe} / \mathrm{Ni}, \mathrm{Fe}_{3} \mathrm{O}_{4}\right.$ or $\left.\mathrm{Fe}_{3-\mathrm{x}} \mathrm{Ni}_{\mathrm{x}} \mathrm{O}_{4}\right]=0.25 \mathrm{~g} \mathrm{~g}^{-1}$ of soil, $\mathrm{L} / \mathrm{S}=1: 1,\left[\mathrm{H}_{2} \mathrm{O}_{2}\right]=2 \mathrm{M} ;\left[\mathrm{K}_{2} \mathrm{~S}_{2} \mathrm{O}_{8}\right]=180 \mathrm{mM}, \mathrm{pH}=8.2 \pm 0.3$.

Figure 6. Effect of oxidant concentration on PCB degradation efficiency in presence of magnetite nanoparticles: $\left[\mathrm{Fe}_{3} \mathrm{O}_{4}\right]=0.25 \mathrm{~g} \mathrm{~g}^{-1}$ of soil, $\mathrm{L} / \mathrm{S}=1: 1,\left[\mathrm{H}_{2} \mathrm{O}_{2}\right]=0.2,1,2 \mathrm{M},\left[\mathrm{K}_{2} \mathrm{~S}_{2} \mathrm{O}_{8}\right]=45,90,180 \mathrm{mM}$, $\mathrm{T}=20 \pm 2{ }^{\circ} \mathrm{C}, \mathrm{pH}=8.2 \pm 0.3$, reaction time: $48 \mathrm{~h}$.

Figure 7. (A) Effect of soil matrix on PCB oxidation: $\left[\mathrm{Fe}_{3} \mathrm{O}_{4}\right]=0.25 \mathrm{~g} \mathrm{~g}^{-1}$ of soil/sand, $\mathrm{L} / \mathrm{S}=1: 1$, $\left[\mathrm{H}_{2} \mathrm{O}_{2}\right]=0.2 \mathrm{M}, 1 \mathrm{M}(0.2 \times 5), 2 \mathrm{M}(0.2 \times 10), \mathrm{pH}=8.2 \pm 0.3, \mathrm{~T}=20 \pm 2{ }^{\circ} \mathrm{C}$, reaction time: $240 \mathrm{~h}$.

Figure 8. Effect of fraction size of the soil on PCB degradation: $\left[\mathrm{Fe}^{0}, \mathrm{Fe} / \mathrm{Ni}\right]=0.25 \mathrm{~g} \mathrm{~g}^{-1}$ of soil, $\mathrm{L} / \mathrm{S}$ $=1: 1, \mathrm{pH}=8.2 \pm 0.3, \mathrm{~T}=20 \pm 2{ }^{\circ} \mathrm{C}$, reaction time: $48 \mathrm{~h}$. 
Figure 1
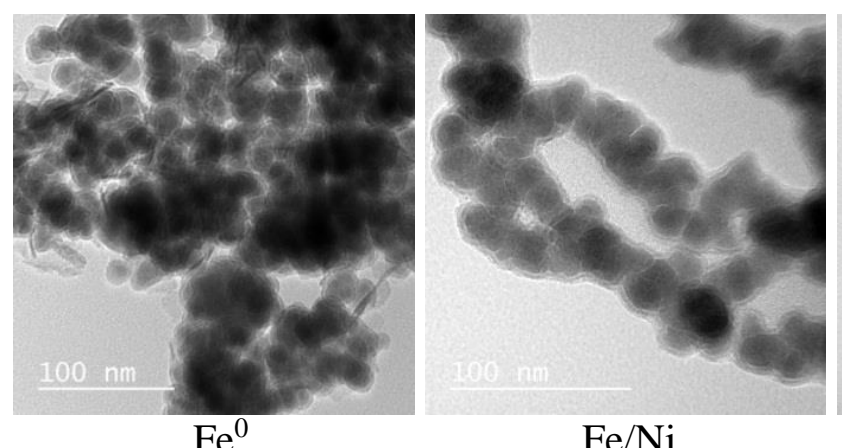

$\mathrm{Fe} / \mathrm{Ni}$

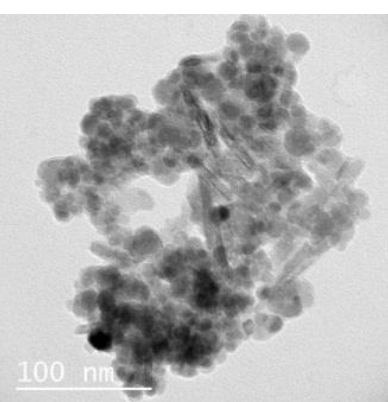

$\mathrm{Fe}_{3} \mathrm{O}_{4}$

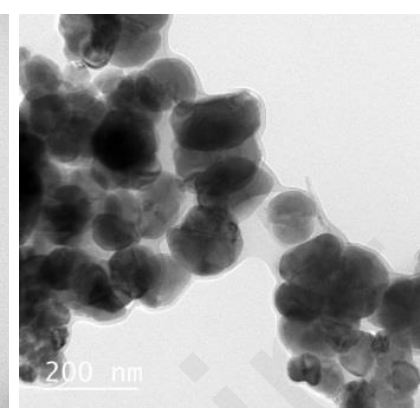

$\mathrm{Fe}_{3 x} \mathrm{Ni}_{\mathrm{x}} \mathrm{O}_{4}$ 
Figure 2

A

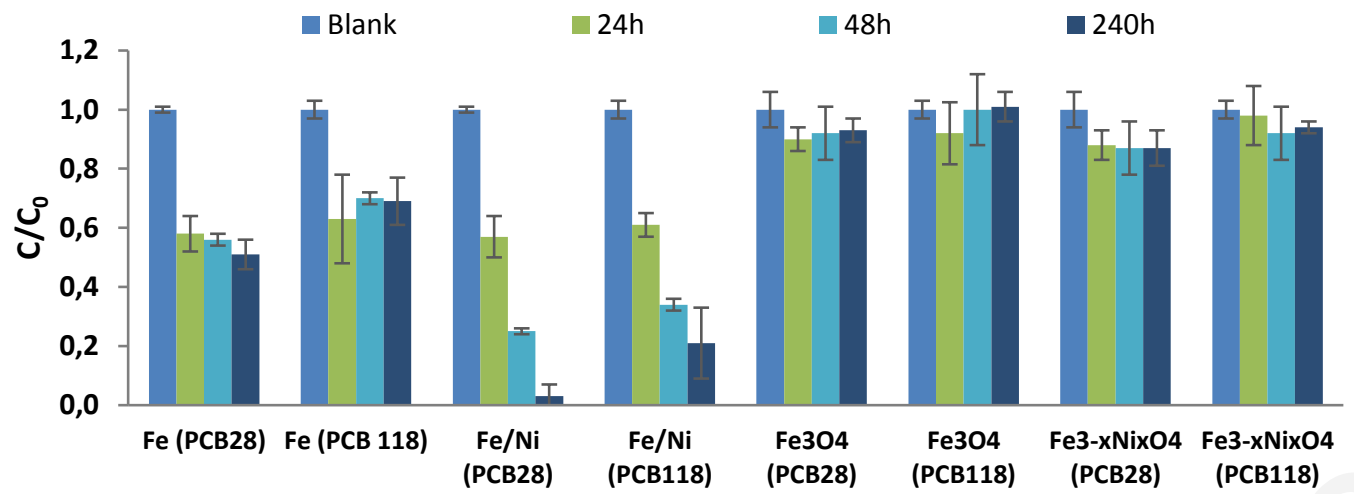

B

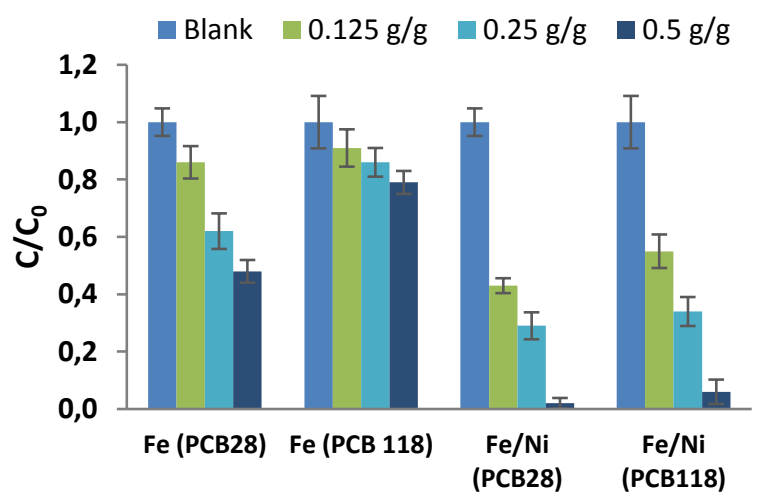


Figure 3

A

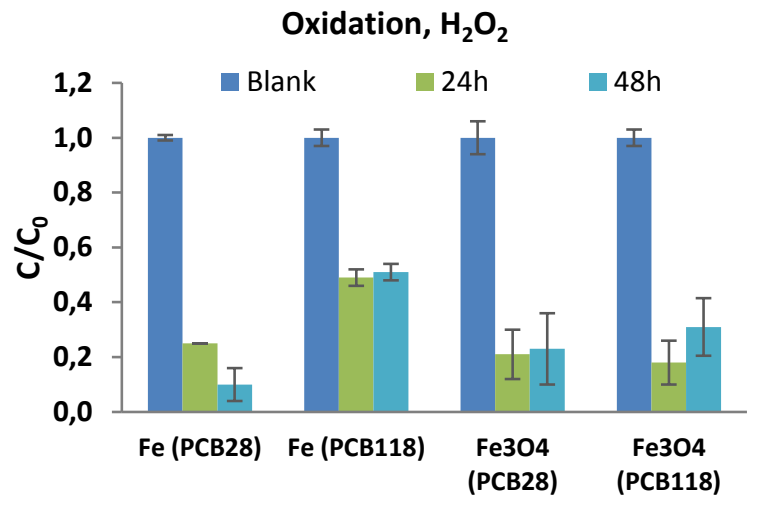

B

Oxidation, $\mathrm{K}_{2} \mathrm{~S}_{2} \mathrm{O}_{8}$



C

Combined approach with $\mathrm{H}_{2} \mathrm{O}_{2} / \mathrm{K}_{2} \mathrm{~S}_{2} \mathrm{O}_{8}$

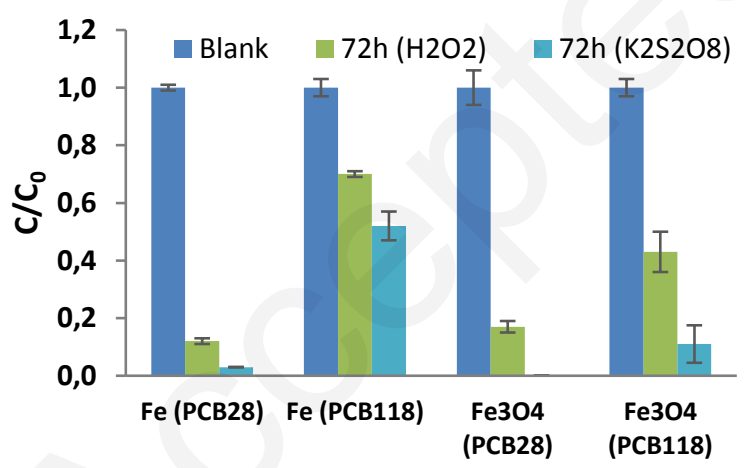




\section{Figure 4}

A

Reductive transformation $\left(\mathrm{Fe}^{0}\right)$

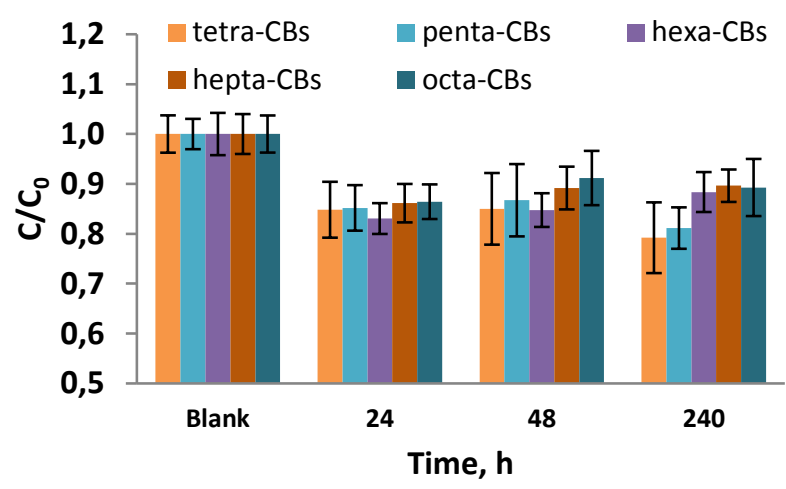

B

Reductive transformation (Fe/Ni)

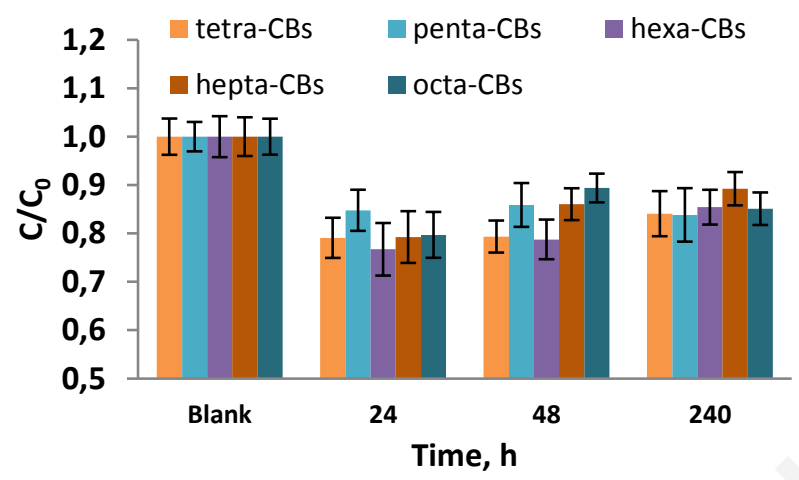

C

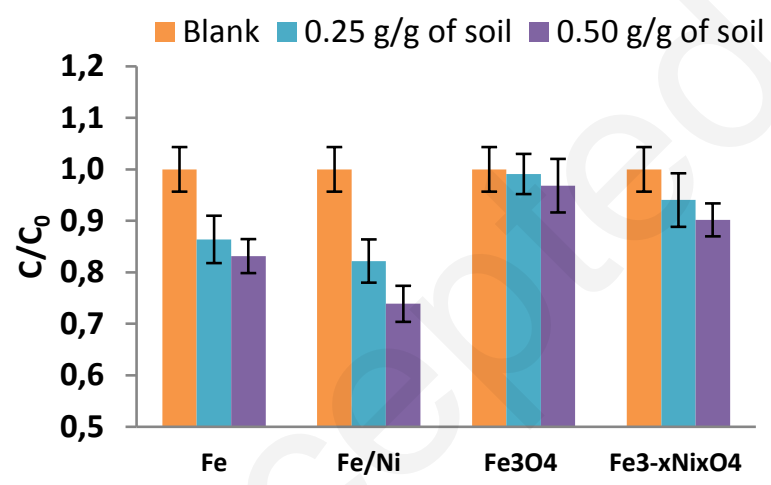




\section{Figure 5}

A

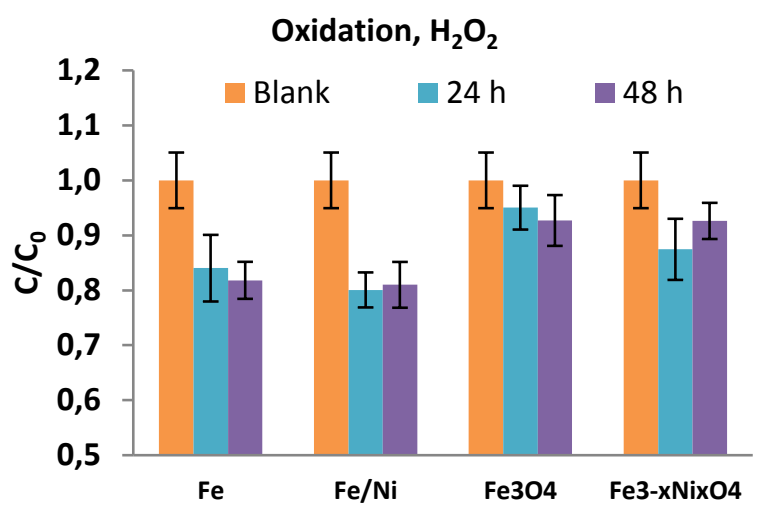

B

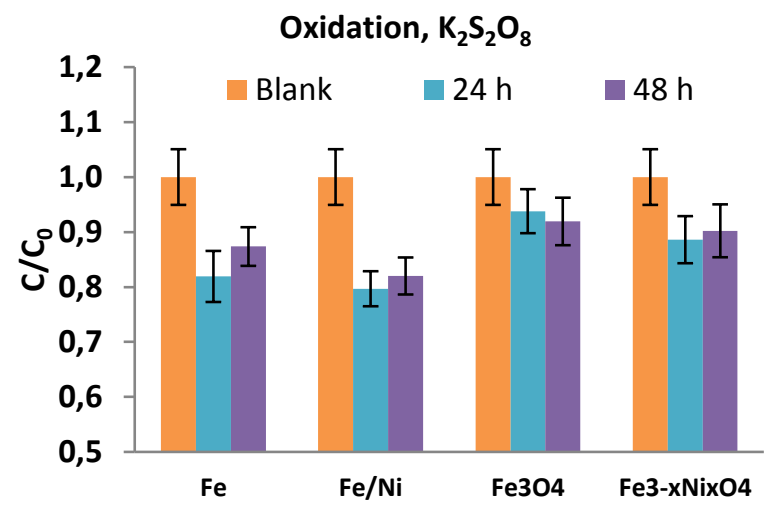

C

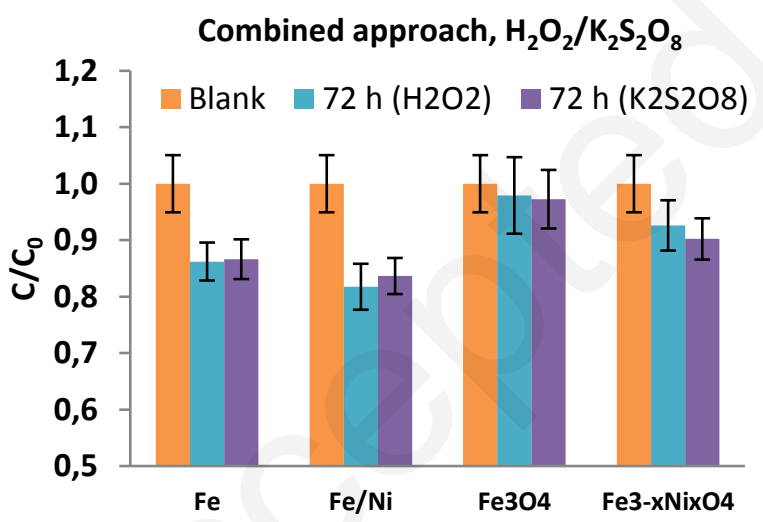


Figure 6

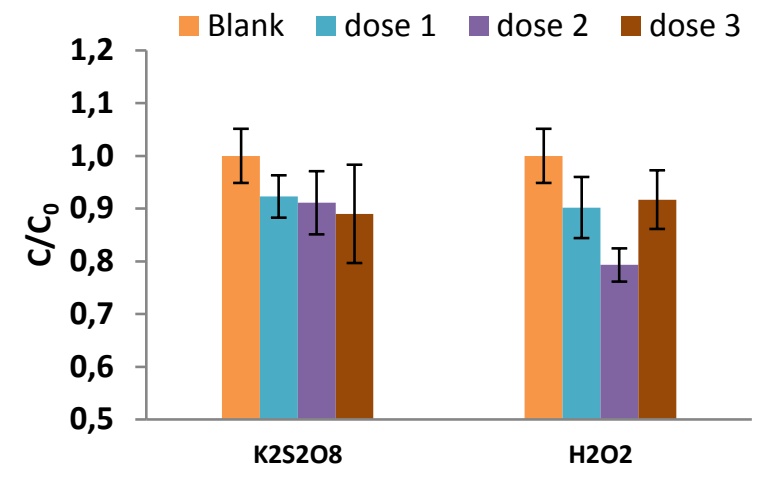




\section{Figure 7}

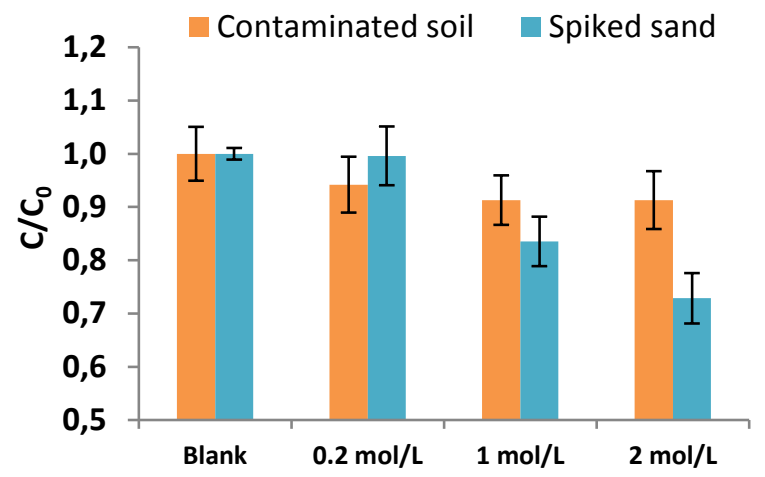


Figure 8

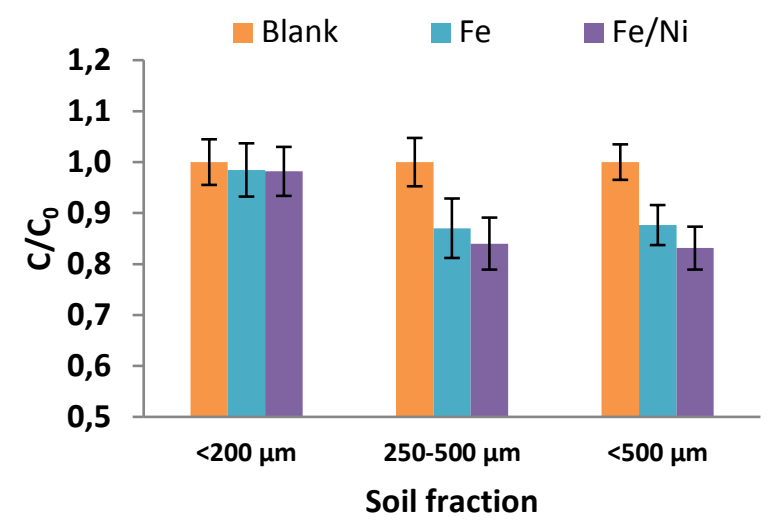

